\title{
Hollow Avowals of Human Rights PROTECTION - TIME FOR AN Australian Federal Bill of Rights?
}

\author{
JULIE CASSIDY*
}

Unlike the constitutions of many nations, such as the United States of America and the Republic of South Africa, the constitutions of the Australian States and Territories and the Commonwealth Constitution Act 1901 (UK) contain no bill of rights. Australia is the only western democracy without a federal bill of rights. The debate regarding the need for a bill of rights necessitates an understanding of what human rights the people of Australia already enjoy. If sufficient protection can be found in existing sources, does Australia really need a federal bill of rights? Opponents of a bill of rights state that we have sufficient protection from arbitrary government intervention in our personal affairs and thus a bill of rights is unnecessary. There are a number of potential sources of human rights in Australia that might provide the suggested existing protection, including the common law, specific domestic legislation, international law and constitutional law. Each of these sources of human rights has, however, important limitations. The focus of this article is on the inadequacy of the Australian constitutions as a source of purported protection. This in turn suggests that an alternative source of rights is needed - a federal bill of rights? In the course of this analysis the author makes suggestions for reform; specifically how a federal bill of rights may address the paucity of constitutional protection.

\section{INTRODUCTION}

Unlike the constitutions of many nations, such as the United States of America and the Republic of South Africa, the constitutions of the Australian States and Territories and the Commonwealth Constitution Act 1901 (UK)

\footnotetext{
* Associate Professor, School of Law, Deakin University, Australia.
} 
('Constitution') contain no bill of rights. ${ }^{1}$ Australia is the only western democracy without a federal bill of rights. ${ }^{2}$ This has been a matter of great debate for some time, a debate recently ${ }^{3}$ re-ignited by the adoption of legislative human rights charters in the State of Victoria ${ }^{4}$ and the Australian Capital Territory. ${ }^{5}$ These developments have led commentators to consider whether the federal government should follow suit and adopt either a legislative, or a constitutional, bill of rights. The contemporary relevance of this issue has been heightened with the recent election (November 2007) of the Rudd Labor federal government. The previous Howard Liberal/National coalition government was openly suspicious of, and hostile to, the introduction of a bill of rights instrument. ${ }^{6}$

\section{A Hollow Denials that there is a Problem}

The debate regarding the need for a bill of rights necessitates an understanding of what human rights the people of Australia already enjoy. If sufficient protection can be found in existing sources, does Australia really need a federal bill of rights? Opponents of a bill of rights state that we have sufficient protection from arbitrary government intervention in our personal affairs and thus a bill of rights is unnecessary. ${ }^{7}$ Such persons declare, 'our

\footnotetext{
${ }^{1}$ As Dawson J noted in Kruger v Commonwealth (1997) 190 CLR 1, 61 the 'Constitution does not contain a Bill of Rights. Indeed the 1898 Constitutional Convention rejected a proposal to include an express guarantee of individual rights...'

${ }^{2}$ See R Cassin, 'Who's afraid of a bill of rights?', The Age (Melbourne), 17 December 2005, 26; 'Protecting the inalienable rights of citizens', The Age (Melbourne), 24 July 2006, 12; H Charlesworth, M Chiam, D Hovell and G Williams, No Country is an Island: Australia and International Law (2006) 64; M McHugh, Does Australia Need a Bill of Rights? (2007) New South Wales Bar Association <www.nswbar.asn.au/docs/resources/lectures/bill_rights.pdf $>$ at 10 October 2008.

${ }^{3}$ A Anderson, 'The wrongs of pushing a Bill of Rights', The Age, (Melbourne), 4 January 2005, 13; J Burnside, 'It's time to uphold our rights', The Age, (Melbourne), 14 December 2006, 21; Cassin, above n 2; R Clement, 'Why we don't need a bill of rights', The Age, (Melbourne), 30 March 2006; 'Protecting the inalienable rights of citizens', The Age, (Melbourne), 24 July 2006, 12; C Evans and S Evans, 'Charter a step forward in protecting human rights', The Age, (Melbourne), 22 December 2005, 15; R Hulls, 'Bill of Rights: What's 'wrong' with protecting our basic rights?', The Age, (Melbourne), 6 January 2006; P Lynch, 'Getting it right on human rights', The Age, (Melbourne), 13 March 2006; A Mason, 'Rights bill a matter for judgment', The Age, (Melbourne), 29 March 2006; F Shiel, 'Victoria to get human rights charter', The Age, (Melbourne), 21 December 2005, 9.

${ }^{4}$ Charter of Human Rights and Responsibilities Act 2006 (Vic).

${ }^{5}$ Human Rights Act 2004 (ACT).

${ }^{6}$ See Cassin, above n 2; 'Protecting the inalienable rights of citizens', above n 3; M Saunders, 'PM won't pick up Fraser's Bill', Weekend Australian, (Sydney), 26 August 2000, 5.

${ }^{7}$ Anderson, above n 3; Clement, above n 3; P Faris, 'Lawyers' picnic for your rights', Herald Sun, (Melbourne) 1 January 2008, 16.
} 
basic rights and freedoms in Australia [are] well protected ..., ${ }^{8}$ These commentators assert that 'here in Melbourne, Mildura, or Maryborough in [2008], we're ok, we don't have the human rights abuses faced by people in other countries'?

However, empirical evidence indicates that the traditional reliance on the common law and responsible government as the ultimate guardians of human rights is no longer sufficient. ${ }^{10}$ Australian society has recently experienced an erosion of civil liberties. Anti-terrorism laws, ${ }^{11}$ for example, now authorise acts contrary to the fundamental civil rights ${ }^{12}$ that underpin the legal and procedural limitations to the police force's general investigatory and detention powers. Most recently we have seen control orders being imposed

\footnotetext{
${ }^{8}$ Faris, above $\mathrm{n} 7$.

9 D Sisely, 'Safeguarding the rights of all Victorians', The Age, (Melbourne), 28 December 2007, 19.

${ }^{10}$ See M Gordon, 'Fraser backs bill of rights', The Age, (Melbourne), 25 August 2000, 1; N Meagher, 'Rights bill bolsters politicians', The Australian, (Sydney), 10 January 2001, 11.

${ }^{11}$ The primary federal anti-terrorism laws are contained in Schedule 1, Part 5.3 (Terrorism), Divisions 100-104, Criminal Code Act 1995 (Cth) and Part 1AA, Division 3A Crimes Act 1914 (Cth). The former legislation details relevant criminal acts. The latter contains relevant police powers pertaining to search and seizure, questioning, arrest and denial of bail and nonparole periods. Division 104 provides for the imposition of control orders. Part II Crimes Act 1914 (Cth) also includes offences in regard to unlawful associations. For further legislation see the extremely comprehensive parliamentary library site: Parliamentary Library, Terrorism Law (2008) Parliament of Australia <http://www.aph.gov.au/library/intguide/law/terrorism.htm> at 10 October 2008.

${ }^{12}$ Australian Lawyers for Human Rights, Submission to the Senate Legal and Constitutional Affairs Inquiry into the Anti-terrorism Bill (No 2) 2005 (2005) Parliament of Australia $<$ http://www.aph.gov.au/senate/committee/legcon_ctte/completed_inquiries/2004-

07/terrorism/submissions/sub139.pdf> at 10 October 2008; Law Council of Australia, Submission to the Senate Legal and Constitutional Affairs Inquiry into the Anti-terrorism Bill (No 2) 2005 (2005) Parliament of Australia <http://www.aph.gov.au/senate/committee/ legcon_ctte/completed_inquiries/2004-07/terrorism/submissions/sub140.pdf $>$ at 10 October 2008; A Lynch and G Williams, What Price Security? Taking Stock of Australia's Anti-Terror Law (2006); J von Doussa, 'Reconciling human rights and counter-terrorism - a crucial challenge' (Paper presented at The Annual James Cook University Mayo Lecture, 12 September 2006), <http://www.hreoc.gov.au/about/media/speeches/speeches_president/2006/ mayo_lecture.html> at 10 October 2008; Human Rights and Equal Opportunity Commission, Submission to the Parliamentary Joint Committee on Intelligence and Security Review of the Power to Proscribe Terrorist Organisations (2007) Human Rights and Equal Opportunity Commission

$<$ http://www.hreoc.gov.au/legal/submissions/2007/proscription_powers_terrorist_org_feb2007 .html > at 10 October 2008; G Williams, The Case for an Australian Bill of Rights: Freedom in the War on Terror (2004), 27-8; M McHugh, 'Terrorism Legislation and the Constitution' (2006) 28 Australian Bar Review 117; McHugh, above n 2.
} 
on Jack Thomas ${ }^{13}$ and David Hicks ${ }^{14}$ under these anti-terrorism laws. The ability to impose such control orders provides a specific example of the tension between anti-terrorism laws and individual rights and liberties in Australia. ${ }^{15}$ Further, despite the report of the government-appointed Security Legislation Review Committee that aspects of these anti-terrorism laws, in particular those relating to banned organisations and the offence of associating with a banned organisation, breached fundamental human rights, the former federal government refused to repeal or amend them. ${ }^{16}$

Immigration laws provide a further contemporary example of the derogation from human rights protection. ${ }^{17}$ Such laws authorise the mistreatment of

\footnotetext{
${ }^{13}$ On 28 August 2007 the first control order was made by the Federal Magistrates Court in relation to Jack Thomas. Particularly relevant in the context of this article, which focuses on the paucity of existing constitutional protections, such control orders were recently held to be constitutionally valid: Thomas v Mowbray (2007) 237 ALR 194. See further B Jagers, Antiterrorism control orders in Australia and the United Kingdom: a comparison (Parliamentary Library, Research Paper No. 28 2007-2008) (2008) Parliament of Australia <www.aph.gov.au/ library/pubs/RP/2007-08/08RP28.htm> at 10 October 2008.

${ }^{14}$ Jabbour v Hicks [2007] FMCA 2139. See further Jagers, above n 13.

${ }^{15}$ See Kirby J's dissent in Thomas v Mowbray (2007) 237 ALR 194. See also Civil Liberties Australia, 'Kirby delivers dissenting masterpiece' (www.cla.asn.au); Amnesty International Australia, Australia: Draconian laws in action undermine Australia's human rights obligations (2006) Amnesty International Australia <http://www.amnesty.org.au/news/ comments/277/> at 10 October 2008; von Doussa, above n 12; Australian Lawyers for Human Rights, above n 12; Lynch and Williams, above n 12; Jagers, above n 13.

16 Security Legislation Review Committee, Report of the Security Legislation Review Committee (2006) <http://www.ag.gov.au/www/agd/rwpattach.nsf/VAP/(03995EABC73F 94816C2AF4AA2645824B) SLRC+Report-

+Version+for+15+June+2006\%5B1\%5D.pdf/\$file/SLRC+Report-

+ Version+for+15+June+2006\%5B1\%5D.pdf>. See also Human Rights and Equal Opportunity Commission, above n 12. The Australian Law Reform Commission has also called for the repeal of the sedition laws, enacted as part of the then federal government's anti-terrorism laws: Australian Law Reform Commission, Fighting words; A Review of Sedition Laws in Australia, Report No 104 (2006) <http://www.austlii.edu.au/au/ other/alrc/publications/ reports/104/ALRC104.pdf $>$. Note that the United Kingdom legislation, including detention powers under s 23 Anti-Terrorism, Crime and Security Act 2001 (UK) and control orders under s 1(1) Prevention of Terrorism Act 2005 (UK) have been held by the House of Lords to effect a deprivation of liberty in breach of the Human Rights Act 1998 (UK): A(FC) v Secretary of State for the Home Department [2004] UKHL 56; Secretary of State for the Home Department $v$ JJ [2007] UKHL 45. See also Secretary of State for the Home Department $v$ MB [2007] UKHL 46; Secretary of State for the Home Department v E [2007] UKHL 47. See further D Feldham, 'Deprivation of Liberty in Anti-Terrorism Law' [2008] Cambridge Law Journal 4; von Doussa, above n 12.

${ }^{17}$ See further HREOC, Summary of Observations following the Inspection of Mainland Immigration Detention Facilities 2007 (2007) HREOC <http://www.hreoc.gov.au/ Human_RightS/immigration/idc2007.html> at 10 October 2008; HREOC, Human Rights and International Law Implications of Migration Bills (2001) HREOC <http://www.hreoc.gov.au/
} 
asylum seekers in breach of international law ${ }^{18}$ through, inter alia, arbitrary indefinite detention. The previous Liberal/National coalition government ignored reports by, among others, the United Nations Human Rights Commission and Human Rights and Equal Opportunity Commission, that its detention regime breached international law. ${ }^{19}$ The current Australian Minister of Immigration and Citizenship, Senator Chris Evans, has stated that 247 people have been identified as having been wrongly detained under immigration laws. ${ }^{20}$ In recent times these detention powers were misused on at least two Australian residents. Cornelia Rau was wrongly detained as an illegal immigrant for almost a year when she was mistaken by immigration authorities for a German tourist. ${ }^{21}$ Vivian Alvarez Solon, an Australian citizen, was wrongly detained and then deported to the Philippines, despite health concerns, because she appeared to be a Filipina. ${ }^{22}$ It appears that the vulnerable in our society, whether mentally ill,${ }^{23}$ homeless,${ }^{24}$ members of

HUMAN_RIGHTS/immigration/migration_bills.html> at 10 October 2008; McHugh, above n 2.

${ }^{18}$ These include Convention Relating to the Status of Refugees 1951, International Covenant on Civil and Political Rights 1966 ('ICCPR'), Convention on the Rights of the Child 1989 ('CROC') and Body of Principles for the Protection of All Persons under Any Form of Detention or Imprisonment Regarding the Situation of Immigrants and Asylum Seekers (1999). See further HREOC, above n 17; A Sathanapally, 'Asylum Seekers, Ordinary Australians and Human Rights' (Working Paper 3, Australian Human Rights Centre, 2004).

${ }^{19}$ See further HREOC, above n 17; J Burnside, 'Australia's treatment of asylum seekers: The view from outside' (Speech delivered on World Refuge Day, Parliament House, 2003) $<$ http://www.smh.com.au/articles/2003/07/08/1057430195786.html> at 10 October 2008. See also Charlesworth et al., above $\mathrm{n} 2$.

${ }^{20}$ Senator C Evans, 'Address to the 2008 National Members' Conference of the Migration Review Tribunal and Refugee Review Tribunal' (Speech delivered at the 2008 National Member's Conference of the Migration Review Tribunal and Refugee Reveiw Tribunal, Melbourne, 29 February 2008) <www.chrisevans.alp.org.au/news/0208/immispeeches2901.php> at 13 October 2008.

${ }^{21}$ See M Palmer, Inquiry into the Circumstances of the Immigration Detention of Cornelia Rau (2005) <www.immi.gov.au/media/publications/pdf/palmer-report.pdf> at 13 October 2008; Parliament of Australia, Parliamentary Library, The Detention of Cornelia Rau; legal issues, Research Brief No 14 (2004-05) <http://www.aph.gov.au/library/Pubs/RB/200405/05rb14.pdf> at 13 October 2008.

${ }^{22}$ See Palmer, above n 21; Commonwealth Ombudsman, Inquiry into the Circumstances of the Vivian Alvarez Matter, (Report No 3 of 2005) <http://www.comb.gov.au/commonwealth/ publish.nsf/AttachmentsByTitle/reports_2005_03_dimia.pdf/\$FILE/alvarez_report03.pdf> at 13 October 2008. See also Department of Immigration, Multicultural and Indigenous Affairs, Response to the Recommendations of the Report of the Commonwealth Ombudsman of the Inquiry Into the Circumstances of the Vivian Alvarez Matter, (Canberra, October 2005); Victorian Immigrant and Refugee Women's Coalition, 'Viviantimeline' (www.virwc.org.au). The Age newspaper has reported that an elderly dementia sufferer was recently wrongly detained consequent on her lack of English language skills, which had led immigration authorities to believe that she was an illegal immigrant: Sisely, above $\mathrm{n} 9$.

${ }^{23}$ See McHugh, above n 2. 
marginalised ethnic/religious groups ${ }^{25}$ or indigenous ${ }^{26}$ Australians, are those most impacted upon by the paucity of effective human rights protections in Australia. $^{27}$

Even the mistreatment of Guantanamo Bay detainees, such as the Australian David Hicks, is relevant to the contemporary mistrust of the sufficiency of existing human rights protections. Leaving aside the arguable general breaches of the Geneva Conventions (1949) and Protocols (1977), in some cases detainees have been held at Guantanamo Bay for years without being charged with any offence, ${ }^{28}$ arguably contrary to, inter alia, international law's prohibition against arbitrary imprisonment. ${ }^{29}$ There have also been allegations of torture of the detainees ${ }^{30}$ contrary to international law's

\footnotetext{
${ }^{24}$ See McHugh, ibid.

${ }^{25}$ The Muslim community, for example, has suffered considerable discrimination generally, but particularly since the introduction of the above anti-terrorism laws. See Australian Muslim Civil Rights Advocacy Network, New Anti-terror Laws and the Muslim Community - a plain English explanation (2005) Australian Muslim Civil Rights Advocacy Network $<$ http://lexus.websitewelcome.com/ amcran/index.php?option=com_content\&task=view\&id= 89\&Itemid=41> at 14 October 2008; HREOC, Annual Report 2006-2007, Ch 9 Race Discrimination

<http://www.humanrights.gov.au/about/publications/annual_reports/2006_2007/pdf/hreoc_ar2 006-07.pdf > at 14 October 2008.

${ }^{26}$ See further the discussion below of the need for protection of aboriginal rights in a federal bill of rights.

${ }^{27}$ See Williams, above n 12, 26; McHugh, above $\mathrm{n} 2$.

${ }^{28}$ In regard to the Australian detainees, Mr David Hicks was held for more than five years without legitimate charges and Mr Mamdouh Habib was held for more than two years without charge prior to his relatively recent release. See further McHugh, above n 2; Senator Linda Kirk 'David Hicks has been detained at Guantanamo Bay US Military base in Cuba without charge for over a year' (Press Release, 17 March 2003). Note that Jack Thomas, the subject of the first control order made in Australia under new anti-terrorism laws, was held by Pakistani authorities for five months without charge. United Kingdom estimates suggest that more than 490 detainees are held in Guantanamo Bay: BBC News, UK calls for Guantanamo closure (2006) BBC News <http://news.bbc.co.uk/1/hi/uk_politics/4759317.stm> at 14 October 2008.

${ }^{29}$ See Rodriguez-Fernandez v Wilkinson 505 F Supp 787 (D Kan 1980) 800; Forti v SuarezMason 672 F Supp 1531 (ND Cal 1987) 1541. Labor Senator for South Australia, Senator Kirk, noted 'Guilty or not, David Hicks cannot be kept in indefinite detention without charge. To do so is a fundamental breach of human rights': Kirk, above $\mathrm{n} 28$.

${ }^{30}$ Detainees have allegedly been starved, forced into stress positions for lengthy periods and more recently accusations have arisen of forcible drug sedation at the hands of US military intelligence officers. In a confidential report in June 2004 the International Committee of the Red Cross reported to the United States government that the treatment of prisoners was tantamount to torture. See further UC Davis Center for the Study of Human Rights in the Americas, ICRC: Analysis (2007) UC Davis Center for the Study of Human Rights in the Americas <http://humanrights.ucdavis.edu/projects/the-guantanamo-testimonials-project/ testimonies/testimonies-of-the-red-cross/icrc-analysis/> at 14 October 2008. Amnesty International has received a massive number of reports in regard to the abuse and torture of
} 
prohibition of state torture. ${ }^{31}$ Again, relevant to the subject analysis, the United States' Bill of Rights 1791 protection against detention without charge ensures that no United States citizens are held in Guantanamo Bay, and the Human Rights Act 1998 (UK) protection of the right to a fair trial underpinned the successful negotiation for the release of English Guantanamo Bay detainees. ${ }^{32}$ These United States and United Kingdom instruments have no Australian counterpart.

\section{B Current Purported Protections and their Inadequacy - Plan of the Article}

What then are the sources of law that the opponents of a bill of rights believe sufficiently protect Australians against such abuses? Protection for human rights might be expected from various legal sources in Australia, including the common law, specific domestic legislation, international law, and State and federal constitutional law. Whilst this article is primarily concerned with constitutional law protections, this analysis is part of a broader debate and the article begins with a brief discussion of each of these sources. The common law and specific legislation are wanting in this regard, and the effect of international law is uncertain.

The article then turns to constitutional law. The constitutions of the Australian States essentially ${ }^{33}$ contain no human rights guarantees. Moreover, the guarantees provided by the Commonwealth Constitution are not only limited, but have generally been read down by the judiciary, leaving them ineffective. This article re-examines four federal constitutional 'protections' that particularly demonstrate this lack of efficacy: ${ }^{34}$

prisoners at Guantanamo Bay and has called for its closure: Amnesty International, USA:

Close Guantanamo and disclose the rest (2005) Amnesty International <http://asiapacific.amnesty.org/library/Index/ENGAMR511012005?open\&of=ENG-2AM> at 14 October 2008. See also Amnesty International, USA: Guantanamo detainees must not be returned to more abuse (2005) Amnesty International <http://www.amnesty.org/en/library/ info/AMR51/121/2005> at 14 October 2008.

${ }^{31}$ See Filartiga v Pena-Irala 630 F 2d 876 (1980), 885; Forti v Suarez-Mason 672 F Supp 1531 (N D Cal 1987), 1541. Such allegations would also be contrary to the Convention against Torture and other Cruel, Inhuman or Degrading Treatment or Punishment (1984) and the Universal Declaration of Human Rights (1948).

${ }^{32}$ Attorney-General Lord Goldsmith, 'Terrorism and Human Rights' (Speech delivered at the Royal United Services Institute Conference) <http://news.bbc.co.uk/1/hi/uk_politics/ 4760031.stm> 14 October 2008.

${ }^{33}$ Constitution Act 1934 (Tas) s 46 guarantees the freedom of conscience and religion.

${ }^{34}$ In light of the existing literature that provides a general commentary on the relevant law regarding these provisions, this article succinctly identifies key limitations that emerge from the case law and provides a critical analysis of the existing law. For a more detailed discussion 
- $\quad$ the right to have property acquired on just terms: section 51(xxxi);

- $\quad$ the right to a jury trial: section 80 ;

- $\quad$ freedom of religion: section 116; and

- $\quad$ freedom from interstate discrimination: section 117.

Given the paucity of explicit constitutional protections, the article goes on to pose a further question, namely whether the framework of the Constitution may provide implied rights that serve as a further source of constitutional protection. It will be seen, however, that the courts have generally taken a constrictive approach to these implied limitations and that the very existence of some of these implied constitutional rights is in doubt. These implied protections certainly do not provide an effective source of human rights protection.

In the course of this constitutional analysis it is suggested that an alternative source of rights is needed - a federal bill of rights. In the context of each of the above constitutional protections reform suggestions are made, drawing on, inter alia, the United States' Bill of Rights (1791), the Canadian Charter of Rights and Freedoms (1982), the Bill of Rights Act 1990 (NZ), the Constitution of the Republic of South Africa 1996 and the Charter of Rights and Responsibilities 2006 (Vic).

The need for a bill of rights is also suggested by the historical discrimination against the Aboriginal peoples of Australia under the Constitution. A glaring hole in the Constitution exists: the absence of any provision protecting Aboriginal rights. In fact, it will be seen that the Constitution was originally drafted to facilitate discrimination against the Aboriginal peoples of Australia. The author contends that the suggested bill of rights should include protections that are specifically aimed at protecting Aboriginal rights.

Finally, the article concludes by placing this analysis in its broader context in regard to whether Australia should adopt a federal bill of rights. To this end the article briefly considers the implications of the analysis in deciding whether Australia should adopt a federal bill of rights.

of existing case law see further P Hanks, P Keyzer and J Clarke, Australian Constitutional Law: Materials and Commentary ( $7^{\text {th }}$ ed, 2004); T Blackshield and G Williams, Australian Constitutional Law and Theory: Commentary and Materials ( $4^{\text {th }}$ ed, 2006). See also McHugh, above $\mathrm{n} 2$. 


\section{SOURCES OF Human RightS IN Australia - NON-CONSTITUTIONAL SOURCES}

What are the sources of law that the opponents of a bill of rights believe sufficiently protect Australians against human rights abuses? There are a number, including the common law, specific domestic legislation, international law and constitutional law. Each of these sources of law has, however, important limitations.

\section{A Common Law}

Common law protections are quite limited and generally are not in the form of express statements of rights. They rather involve protective presumptions utilised in statutory interpretation ${ }^{35}$ or assumptions of liberties in areas where such liberties are not prohibited by law. ${ }^{36}$ Obviously, these presumptions utilised in statutory interpretation are rebuttable and may be overridden by clear legislation. ${ }^{37}$ Furthermore, in limited cases the common law recognises substantive rights, for example, the right to a fair trial. ${ }^{38}$ However, even these 'rights' are subject to legislative abrogation. ${ }^{39}$ For example, the right to a fair trial, as stated in Dietrich $v R,{ }^{40}$ was partially legislatively reversed by the Crimes Act 1958 (Vic), section 360A.

\section{B Domestic Legislation}

Further human rights protections can be found in specific pieces of domestic legislation. Well-known examples of these include the Racial Discrimination Act 1975 (Cth), the Sexual Discrimination Act 1984 (Cth), the Equal Opportunity Act 1984 (SA), the Equal Opportunity Act 1984 (WA) and the Equal Opportunity Act 1995 (Vic). These specific legislative protections are

\footnotetext{
${ }^{35}$ See further J Spigelman, 'The Common Law Bill of Rights' (Lecture delivered at 2008 McPherson Lectures, University of Queensland, 10 March 2008) <www.lawlink.nsw.gov.au/ lawlink/supreme_court/11_sc.nsf/vwFiles/spigelman100308.pdf/\$file/spigelman100308.pdf $>$ at 14 October 2008.

${ }^{36}$ Constitutional Commission, Final Report of the Constitutional Commission (1988), 447; McHugh, above $\mathrm{n} 2$.

${ }^{37}$ See further Spigelman, above $\mathrm{n} 35$.

${ }^{38}$ Dietrich v R (1992) 177 CLR 292, 362 (Gaudron J), 326 (Deane J); Re Tracey; Ex parte Ryan (1989) 166 CLR 518, 579 (Deane J); Re Nolan; Ex parte Young (1991) 172 CLR 460, 493 (Gaudron J).

${ }^{39}$ Obviously, the interpretative presumptions are rebuttable presumptions that may also be overridden by clear legislation. See further Spigelman, above $\mathrm{n} 35$.

40 (1992) 177 CLR 292.
} 
generally ${ }^{41}$ limited in subject matter, particularly to cases of racial and sexual discrimination, ${ }^{42}$ rather than protecting all basic civil liberties.

Moreover, as they are legislatively based, these protections are subject to government's legislative powers. For example, the operation of the Racial Discrimination Act 1975 (Cth) was excluded by amendments to the Native Title Act 1993 (Cth) ${ }^{43}$ that allow for, inter alia, the racially discriminatory extinguishment ${ }^{44}$ of Aboriginal title since the decision in Wik Peoples $v$ Queensland. ${ }^{45}$ Apart from very specific legislative amendments that favoured the interests of, among others, mining and pastoralist concerns to the detriment of Aboriginal peoples, the legislation also contains explicit statements suspending the operation of the Racial Discrimination Act 1975 (Cth). For example, section 7(2) of the Native Title Act 1993 (Cth) expressly provides that the Racial Discrimination Act 1975 (Cth) does not apply to the validation of past acts that have abrogated native title rights under the Native Title Amendment Act 1998 (Cth).

More recently, the operation of the Racial Discrimination Act 1975 (Cth) was again excluded by the Liberal/National coalition government in order to facilitate its intervention in Northern Territory Aboriginal communities. Section 132(2) of the Northern Territory National Emergency Response Act 2007 (Cth) (NTNER Act) excludes any acts done under the Act from the operation of Part II of the Racial Discrimination Act 1975 (Cth). It is beyond

\footnotetext{
${ }^{41}$ Leaving aside the Charter of Human Rights and Responsibilities Act 2006 (Vic) and the Human Rights Act 2004 (ACT). These, of course, are limited by the territorial boundaries of their respective jurisdictions.

${ }^{42}$ See for example, the Racial Discrimination Act 1975 (Cth) and the Sexual Discrimination Act 1984 (Cth). Even more generic legislation, such as the Anti-Discrimination Act 1977 (NSW) is quite specific as to the categories of discrimination prohibited under the Act.

${ }^{43}$ Through the Native Title Amendment Act 1998 (Cth).

${ }^{44}$ That facilitating the extinguishment of aboriginal title is in itself racially discriminatory is not only self-evident, but supported by precedent. In Mabo v Queensland (1988) 166 CLR 186 ('Mabo 1') the High Court held that the singling out of aboriginal title for legislative extinguishment under the Queensland Coast Islands Declaratory Act 1985 (Qld) offended the principle of equality found in s 10 of the Racial Discrimination Act 1975 (Cth). As the rights protected by this provision include the right to own and inherit property, the arbitrary extinguishment of aboriginal title was held to be contrary to the Act. Subsequently, in Western Australia v Commonwealth (1995) 183 CLR 373 ('Native Title case') the High Court held that the conversion of the aboriginal title to a diminished statutory form of title under s 7 Land (Titles and Traditional Usage) Act 1993 (WA) was also contrary to the right of equality protected by s 10 Racial Discrimination Act 1975 (Cth). As affirmed in Attorney-General (NT) $v$ Ward [2003] FCAFC 283, [117] the Racial Discrimination Act 1975 (Cth) is breached where a law provides for 'differential treatment of land holding according to race' and aboriginal title 'characteristically is held by members of a particular race'.

${ }^{45}$ (1996) 187 CLR 1.
} 
the scope of this article to discuss the appropriateness of the intervention. As is implicit in section 132(2) of the NTNER Act, the intervention is racially discriminatory. The legislation impacts only on Aboriginal communities and Aboriginal lands ${ }^{46}$ and thus involves an unlawful ${ }^{47}$ distinction on the basis of race. Thus, contemporary events suggest that existing legislative provisions are not sufficient to protect the rights of, particularly, politically marginalised parts of Australian society, such as Aboriginal Australians.

\section{International Law}

International law provides a further potential source of human rights protection in Australia. Today innumerable declarations, instruments, protocols and treaties protecting human rights exist. ${ }^{48}$ Again, however, there are important barriers to international law providing effective protection to individuals. International law has traditionally been seen as the domain of nation states and not individuals. ${ }^{49}$ Moreover, individuals continue to face procedural hurdles when seeking to enforce international human rights norms. In particular Article 34, paragraph 1 of the Statute of the International Court of Justice 1945, which provides for locus standi before the ICJ, states that 'Only states may be parties before the Court'. ${ }^{50}$ While individuals may

\footnotetext{
${ }^{46}$ See further Northern Territory National Emergency Response Act 2007 (Cth).

${ }^{47}$ In breach of s 9 Racial Discrimination Act 1975 (Cth).

48 Some of the major international treaties include: Charter of the United Nations 1945; Universal Declaration of Human Rights 1948; Convention on the Prevention and Punishment of the Crime of Genocide 1948; Geneva Conventions on the Protection of Victims of Armed Conflict 1949 and Protocols 1977; European Convention on Human Rights 1950 (as amended by Protocol 11, 1998); International Covenant on Civil and Political Rights 1966; International Covenant on Economic, Social and Cultural Rights 1966; International Convention on the Elimination of All Forms of Racial Discrimination 1966; Convention on the Elimination of all Forms of Discrimination against Women 1979; Convention against Torture and other Cruel, Inhuman or Degrading Treatment or Punishment 1984; Convention on the Rights of the Child 1989; United Nations Declaration on the Rights of Indigenous Peoples 2007.

${ }^{49}$ See especially the works of Oppenheim, the chief exponent of the traditional theory. He asserts that an 'individual human being ... is never directly a subject of International Law... But what is the real position of individuals in International Law, if they are not subjects thereof? The answer can only be that they are objects of the Law of Nations': International Law (1905), 344. The author has suggested elsewhere that state practice, as evidenced in the declarations of the judiciary and the many treaties and conventions guaranteeing human rights, reveals a consensus of opinion acknowledging the individual as the recipient of international rights: $\mathbf{J}$ Cassidy, 'Emergence of the Individual as an International Juristic Entity: Enforcement of International Human Rights’ (2004) 9(2) Deakin Law Review 533.

${ }^{50}$ See further R Higgins, 'Role of litigation in implementing human rights' [1999] AJHR 19; J Cassidy, 'The Domestic Enforcement of Human Rights: The Relationship between Customary
} 
petition the United Nations' Human Rights Commission, alleging human rights abuses, the Commission lacks an effective enforcement mechanism. The enforcement of the Commission's decisions is left in the hands of the particular member state, which is often the offending entity. In this regard it is particularly relevant to note that the previous Liberal/National ${ }^{51}$ coalition government consistently refused to address international findings of breaches of human rights. ${ }^{52}$ This government merely rebuked the relevant committee for its findings against Australia and asserted that the United Nations was interfering in domestic affairs. ${ }^{53}$ Thus, despite the individual petition mechanism of the Human Rights Commission, the Commission has not proved able to provide an effective international forum for the protection of human rights.

Moreover, international law is in itself a vulnerable source of rights. Customary international law can be overridden by express domestic legislation. While this results in Parliament being in breach of international law, the courts are bound to apply the infringing law. Thus in Polites $v$ Commonwealth $^{54}$ the High Court was forced to uphold conscription legislation that extended to resident aliens, even though this was legislation contrary to customary international law. ${ }^{55}$ Further, conventional international law, treaties and conventions, are not enforceable in Australia until formally incorporated into domestic law. For example, despite the Fraser

International Law and Municipal Law' (Paper presented at the Public Health and Human Rights Conference, Italy, 9 June 2007).

${ }^{51}$ The mechanism did prove effective under the previous Keating Labor federal government. Thus, in response to the decision Toonen v Australia (1994) 1-3 Int Human Rts Rep 97, the federal Parliament passed legislation which rendered inoperative provisions of the Tasmanian Criminal Code that criminalised consensual homosexual acts in private. In time the Criminal Code was amended to reflect this federal legislative change.

${ }^{52}$ Charlesworth, above n 2, 64, 83. These decisions include Hagan v Australia, 4 March 1992; A v Australia, 30 March 1997; Winata v Australia, 18 August 2001; Rogerson v Australia, 15 March 2002; Young v Australia, 6 August 2003; Cabal and Bertran v Australia, 19 September 2003; Bakhtiyari v Australia, 6 November 2003; Brough v Australia, 27 April 2006; D \& Ev Australia, 25 July 2006. See further Charlesworth, above n 2, 83-91.

${ }^{53}$ See, for example, then Prime Minister John Howard's response to the UN Committee on the Elimination of Racial Discrimination Report on the failure to apologise or offer redress to the stolen generations where he asserted that 'We are not told what to do by anybody': ABC Radio, 'The Hon John Howard MP: Radio Interview with Sally Sara', AM, 18 February 2000. See also then Foreign Minister Alexander Downer's response to a decision of the UN Committee on the Elimination of Racial Discrimination that 'If a UN Committee wants to play domestic politics here in Australia, then it will end up with a bloody nose': ABC Television, 7.30 Report, 31 March 2000. See also Alexander Downer, 'Government to Review UN Treaty Committees', (Press Release, 20 March 2000).

${ }^{54}$ (1945) 70 CLR 60.

${ }^{55}$ Ibid 72 (Latham CJ). 
Liberal/National coalition government ratifying the International Covenant on Civil and Political Rights 1966 ('ICCPR') 28 years ago, there has been no federal legislation, apart from the Racial Discrimination Act 1975 (Cth) and Sexual Discrimination Act 1984 (Cth), that has comprehensively incorporated the Convention into domestic law. ${ }^{56}$

\section{CONSTITUTIONAL 'SAFEgUARDS' OF Human RIGHTS IN AUSTRALIA}

\section{A Acquiring Property on Just Terms}

Turning to the analysis of the existing constitutional protections, section 51(xxxi) provides for the right to have property acquired on just terms. More specifically, section 51(xxxi) provides that the Commonwealth has power to 'make laws ... with respect to ... [t]he acquisition of property on just terms from any State or person in respect of which the Parliament has power to make laws' ${ }^{57}$ At first glance, this does not look like a constitutional human rights protection. It seems designed to ensure that the Commonwealth enjoys the legislative authority to compulsorily acquire property, including State property. ${ }^{58}$ However, section 51(xxxi) was designed to have a dual purpose. ${ }^{59}$ It was also intended to provide a constraint on the compulsory acquisition power and ensure that whenever the Commonwealth exercises the power, it must do so on just terms. ${ }^{60}$ Thus the section was 'intended to recognise the principle of the immunity of private and provincial property from interference by the federal authority, except on fair and equitable terms'. ${ }^{61}$ However, from the outset it must be noted that section 51(xxxi) does not guarantee that your home cannot be compulsorily acquired. It only prevents

\footnotetext{
${ }^{56}$ As McHugh notes, Australia has also failed to comply with Article 2 of the ICCPR which requires that individuals must have access to 'effective and enforceable remedies' if their rights are violated: above n 2. See also E Evatt, 'Bill of Rights and International Standards' (Paper presented at the Bill of Rights Conference, Sydney, 21 June 2002) 2.

${ }^{57}$ Note that the requirement that the compulsory acquisition relate to a matter 'in respect of which the Parliament has power to make laws' requires that a law passed under s 51(xxxi) must also be supported by another legislative head of power: PJ Magennis Pty Ltd $v$ The Commonwealth (1949) 80 CLR 382, 402-3 (Latham CJ).

${ }^{58}$ See Dixon J in Grace Bros Pty Ltd v The Commonwealth (1946) 72 CLR 269, 290-1.

${ }^{59}$ Bank of New South Wales v Commonwealth (1948) 76 CLR 1, 349-50.

${ }^{60}$ Johnson Fear \& Kingham v Commonwealth (1943) 67 CLR 314, 318; Bank of New South Wales $v$ Commonwealth (1948) 76 CLR 1, 349-50.

${ }^{61}$ Quick and Garran, The Annotated Constitution of the Australian Commonwealth (1901), 641.
} 
the power being exercised arbitrarily. ${ }^{62}$ It merely provides that the compulsory acquisition must be on just terms; it must be fair, ${ }^{63}$ balancing the community's interests against the interests of the person whose property is to be taken. ${ }^{64}$

There are a number of flaws in section 51(xxxi) as a source of constitutional protection, flaws that should be addressed through reform. First, section 51(xxxi) applies only to the Commonwealth. There is no equivalent provision in the State Constitutions. Section 51(xxxi) does not apply to a compulsory acquisition by a State ${ }^{65}$ unless the federal government has funded the compulsory acquisition. ${ }^{66}$ It is also unclear whether section 51(xxxi) applies to the Territories, in particular the federal government's use of section 122 of the Constitution (the 'Territories' power) ${ }^{67}$ As with the Canadian Charter of Rights and Freedoms, ${ }^{68}$ the terms of any bill of rights instrument should extend to the State and Territory governments, not just the federal government.

Second, there is merit in including a provision similar to that found in section 25 Constitution of the Republic of South Africa 1996 that ensures that any expropriation of property must be under a law of general application. This would prevent the property rights of marginalised members of the community being targeted by the government through private Acts of Parliament. Historically, examples of such governmental actions can be found in the

\footnotetext{
${ }^{62}$ Grace Bros Pty Ltd v The Commonwealth (19946) 72 CLR 269, 290-1 (Dixon J).

${ }^{63}$ Nelungaloo v Commonwealth (1948) 75 CLR 495, 569.

${ }^{64}$ Ibid.

${ }^{65}$ Pye $v$ Renshaw (1951) 84 CLR 58, 79-80. See also Durham Holdings Pty Ltd $v$ The State of New South Wales (2000) 205 CLR 399, 409-10 (Gaudron, McHugh, Gummow and Hayne JJ), 425 (Kirby J), 433 (Callinan J).

${ }^{66}$ Such funding could be through, for example, a s 96 grant to the State: Pye v Renshaw (1951) 84 CLR 58, 83.

${ }^{67}$ While in Teori Tau v Commonwealth (1969) 119 CLR 564 the High Court unanimously held that the power under s 122 was absolute and s 51(xxxi) did not restrict the Commonwealth's power to acquire property in the Territories, this was later doubted in Newcrest Mining (WA) Ltd v Commonwealth (1977) 190 CLR 513, 567, 569 (Gaudron J), 603, 614 (Gummow J), 652, 661-2 (Kirby J). This issue is, however, now effectively moot as the self-government legislation (Northern Territory (Self-Government) Act 1978 and Australian Capital Territory (Self-Government) Act 1988) effectively overrules Teori Tau v Commonwealth (1969) 119 CLR 564.

${ }^{68}$ Note that, strangely, the Canadian Charter of Rights and Freedoms and the New Zealand Bill of Rights Act 1990 (NZ) do not include an actual 'property' protection clause.
} 
dissolution of the Adelaide Company of Jehovah's Witnesses ${ }^{69}$ and the dissolution of the Builders Labourers Federation in $1986 .{ }^{70}$

Third, and most importantly, any protection should extend to compulsory acquisitions as a matter of substance, not just form. There are a number of existing limitations to the operation of section 51(xxxi) which mean it will not always apply to what is in substance a compulsory acquisition. Section 51(xxxi) applies only if there is a compulsory acquisition. ${ }^{71}$ It does not apply if the Commonwealth negotiates an agreement for the acquisition. ${ }^{72}$ For section 51(xxxi) to apply, the Commonwealth must acquire a proprietary interest in the subject property, not merely constrain its use. ${ }^{73}$ Similarly, the courts have asserted that section 51(xxxi) applies only to a law that results in an acquisition of property, as opposed to one that merely diminishes the content of a property right. $^{74}$ Section 51 (xxxi) has also been held to be inapplicable to laws that make a 'genuine adjustment of competing claims, rights and obligations in the common interests between parties who stand in a particular relationship'. ${ }^{75}$ Moreover, the courts have asserted that statutory rights can be acquired without compliance with section 51(xxxi). Effectively the courts have said that if a proprietary right was created by statute, then it can be reduced by statute. ${ }^{76}$ These limitations have wrongly allowed form to prevail over what is in substance a compulsory acquisition.

\footnotetext{
${ }^{69}$ Adelaide Company of Jehovah's Witnesses v Commonwealth (1943) 67 CLR 116.

${ }^{70}$ Builders Labourers' Federation (Cancellation of Registration - Consequential Provisions) Act 1986 (Cth). See further L Ross, Dare to Struggle, Dare to Win! : Builders Labourers fight Deregistration 1981-94 (2004).

${ }^{71}$ Poulton v Commonwealth (1953) 89 CLR 543, 573.

${ }^{72}$ John Cooke \& Co Pty Ltd v Commonwealth (1924) 34 CLR 269, 282; Trade Practices Commission v Tooth \& Co Ltd (1979) 142 CLR 397, 417.

${ }^{73}$ Thus in Commonwealth $v$ Tasmania (1983) 158 CLR 1, 145, 181, 246-8, members of the High Court held that s 51(xxxi) did not apply to the subject law that prevented the State of Tasmania using certain (world heritage listed) lands without the Commonwealth's consent, as there was no vesting of a proprietary interest in the land in the Commonwealth.

${ }^{74}$ Australian Tape Manufacturers Association Ltd v Commonwealth (1993) 176 CLR 480, 528 (Dawson and Toohey JJ); Mutual Pools \& Staff Pty Ltd v Commonwealth (1994) 179 CLR 155, 185 (Deane and Gaudron JJ); Commonwealth $v$ WMC Resources Ltd (1998) 194 CLR 1, $70-1$.

${ }^{75}$ Health Insurance Commission v Peverill (1994) 179 CLR 226, 236. See also Airservices Australia v Canadian Airlines (1999) 202 CLR 133. Note, however, Gummow and Callinan JJ's criticism of this principle: Airservices Australia v Canadian Airlines (1999) 202 CLR 133, 299, 312. Thus a law reducing Medicare benefits was said not to be subject to s 51(xxxi): Health Insurance Commission v Peverill (1994) 179 CLR 226, 236.

${ }^{76}$ Health Insurance Commission v Peverill (1994) 179 CLR 226, 237 (Mason CJ, Deane and Gaudron JJ); Georgiadis v AOTC (1994) 179 CLR 297, 305-6 (Mason CJ, Deane and Gaudron $\mathrm{JJ}$ ). This reasoning has been used to exclude from the operation of s 51(xxxi) legislation that has diminished intellectual property rights (Nintendo Co Ltd v Centronics Systems Pty Ltd
} 
Fourth, the question of the absoluteness of the protection then needs to be addressed. Under the current law in Australia, while generally the legislative powers specified in, inter alia, section 51 of the Constitution, are said to be subject to section $51(\mathrm{xxxi}){ }^{77}$ the High Court has held that in certain cases legislative powers ${ }^{78}$ may be used to compulsorily acquire property other than on just terms. Is it appropriate for the courts to conclude that it is express or implied in a section of the Constitution that legislative powers are not subject to section 51(xxxi)?

Should there be an absolute freedom from compulsory acquisition? The Fifth Amendment of the United States' Bill of Rights provides a right not to be deprived of property without due process of law. As Dixon J noted in Grace Bros Pty Ltd $v$ The Commonwealth ${ }^{79}$ this provision appropriately has as its primary purpose the protection of the citizen, rather than extending an acquisition power to the government.

Could the absoluteness of the protection be abridged in times of national emergency? ${ }^{80}$ Section 37 of the Constitution of the Republic of South Africa 1996 allows certain rights to be abridged in the case of a state of emergency. The Table of non-derogable rights included in section 37(5) does not include the protection of property rights under section 25 , but rather is confined to rights such as the right to equality, right to human dignity and right to life. Further, section 25(2) allows for the expropriation of property for a 'public purpose or in the public interest'. However, the expropriation must not be

(1994) 181 CLR 134), petroleum exploration rights (Commonwealth $v$ WMC Resources Ltd (1998) 194 CLR 1, 38, 51) and Medicare benefits (Health Insurance Commission v Peverill (1994) 179 CLR 226, 237).

${ }_{77}$ Attorney-General (Cth) v Schmidt (1961) 105 CLR 361, 372; Commonwealth v Tasmania (1983) 158 CLR 1, 145 (Mason J) ('Tasmanian Dam case').

${ }^{78}$ For example, s 51(i) ('trade and commerce' power: Airservices Australia v Canadian Airlines (1999) 202 CLR 133, 180-1, 251, 304-5); s 51(ii) ('taxation' power: MacCormick v Commissioner of Taxation (Cth) (1984) 158 CLR 622; Australian Tape Manufacturers Association v Commonwealth (1993) 176 CLR 480, 508-10 (Mason CJ, Brennan, Deane and Gaudron JJ)); s 51(vi) ('defence' power: Attorney-General (Cth) v Schmidt (1961) 105 CLR 361), s 51(xvii) ('bankruptcy and insolvency' power: Attorney-General (Cth) v Schmidt (1961) 105 CLR 361); and s 51(xviii) ('intellectual property' power: Nintendo Co Ltd v Centronics Systems Pty Ltd (1994) 181 CLR 134, 160-1 (Mason CJ, Brennan, Deane, Toohey, Gaudron and McHugh JJ)).

${ }^{79}$ (1946) 72 CLR 269, 290-1.

${ }^{80}$ Charter of Rights and Responsibilities 2006 (Vic) s 11(3)(b) allows the freedom from forced labour to be breached in times of national emergency. However, the national emergency qualification does not provide a basis for abridging the right not to be deprived of property under section 20 of the Charter. 
arbitrary, it must be effected through a general law, and just compensation must be paid.

Alternatively, the right not to be deprived of property could be subject to a general limitation that it may be subject to reasonable laws. Section 20 of Victoria's Charter of Rights and Responsibilities 2006, for example, provides a right not to be deprived of property 'other than in accordance with law'. Moreover, all provisions of the Charter are subject to reasonable limits under law: section 7(2). Similarly, under section 36(1) of the Constitution of the Republic of South Africa 1996 all protections, including the protection of property rights under section 25 , may be circumscribed by general legislation where the 'limitation is reasonable and justifiable in an open and democratic society ...'

Alternatively, the focus could shift from a right not to be deprived of property, to a guarantee that the terms of any acquisition will be just, and that any consequent compensation will be fair. ${ }^{81}$ Sections $25(2)$ and (3) of the Constitution of the Republic of South Africa 1996 provide in detail for a right to compensation for an expropriation of property. This includes a statement that the 'amount of the compensation and the time and manner of payment must be just and equitable, reflecting an equitable balance between the public interest and the interests of those affected, having regard to all the circumstances ...'. Section 25(3) of the Constitution of the Republic of South Africa 1996 then details factors relevant to the determination of a just payment, such as current use of the land, its market value, the extent of any state investment/subsidy and the purpose of the expropriation. The Constitution of the Republic of South Africa 1996 provides extremely useful guidelines for an Australian protection against the deprivation of property.

\section{B Trial by Jury}

The right to trial by jury is supposedly protected by section 80 of the Constitution. The section provides in part that: 'The trial ${ }^{82}$ on indictment of any offence against any law of the Commonwealth shall be by jury.' It will be seen that section 80 is subject to a number of major limitations that render it ineffective as a human rights protection.

\footnotetext{
${ }^{81}$ Note that the Charter of Rights and Responsibilities 2006 (Vic) s 20 does not include a 'just compensation' clause.

${ }^{82}$ As s 80 is confined to the process of 'trial' and thus has no application to sentencing: Cheung $v$ The Queen (2001) 209 CLR 1, 24.
} 
The right to trial by our peers is part of the broader notion that individuals should not be subject to arbitrary detention. ${ }^{83}$ The right to a jury trial is one of the pillars of our criminal justice system that sets our society apart from police states. Thus as Deane J declared in Kingswell $v R:^{84}$

The guarantee of s 80 of the Constitution was not the mere expression of some casual preference for one form of criminal trial. It reflected a deepseated conviction of free men and women about the way in which justice should be administered in criminal cases. That conviction finds a solid basis in an understanding of the history and functioning of the common law as a bulwark against the tyranny of arbitrary punishment.

Given the importance of trial by jury, these shortcomings in its protection should be addressed through reform. First, as with section 51(xxxi), section 80 is limited by its express terms so as to apply only to Commonwealth laws. ${ }^{85}$ There is no equivalent provision in the State constitutions ${ }^{86}$ and the applicability of section 80 to the Territories is uncertain. ${ }^{87}$ Nevertheless, it would be desirable to extend any right to a jury trial to those charged under State and Territory law, not just those charged under federal law.

Second, and most importantly, section 80 has been interpreted as a meaningless tautology and needs to be rephrased so that it provides effective protection. Narrowly construed, section 80 states that 'trial by jury shall be by jury'. The reason for this tautology lies in the fact that the technical meaning of an indictable offence is one that is tried by judge and jury, while a summary offence is tried by judge alone. This tautology has allowed the Australian judiciary to conclude that section 80 requires that, if the subject offence is an indictable offence, there must be a jury trial, but that it does not compel the Commonwealth to ensure that serious offences are classified as indictable offences. ${ }^{88}$ As long as the Commonwealth chooses to make a crime a summary offence, no matter how serious the offence nor how severe the

\footnotetext{
${ }^{83}$ Kingswell v R (1985) 159 CLR 264, 298 (Deane J).

${ }^{84}$ (1985) 159 CLR 264, 298.

${ }^{85}$ Byrnes v The Queen (1999) 199 CLR 1, 32 (Gaudron, McHugh, Gummow and Callinan JJ), 39 (Kirby J).

${ }^{86}$ Note that the Charter of Rights and Responsibilities 2006 (Vic) does not include a right to a jury trial, merely to a fair and public hearing: s 24(1). Similarly, s 35(3) of the Constitution of the Republic of South Africa 1996 only provides a right to a 'fair trial'.

${ }^{87}$ In $R v$ Bernasconi (1915) 19 CLR 629, 635 the courts asserted the phrase 'laws of the Commonwealth' - that implicitly excludes the laws of the territories. In Kruger $v$ Commonwealth (1997) 190 CLR 1, the court was divided on the matter.

${ }^{88} R$ v Archdall and Roskruge; ex parte Carrigan and Brown (1928) 41 CLR 128, 136, 139-40.
} 
consequent punishment, ${ }^{89}$ there is no right to a jury trial. ${ }^{90}$ Thus the reference to an indictable offence in section 80 needs to be replaced by a criterion that is tied to the seriousness of the offence. For example, section 11(f) of the Canadian Charter of Rights and Freedoms provides a right to a jury trial where the "maximum punishment for the offence is imprisonment for five years or a more severe punishment'. Under section 24(e) of the Bill of Rights Act 1990 (NZ) the minimum period of imprisonment triggering the right to a jury trial is only three months. Setting a period of imprisonment as the keystone for the application of the protection is preferable to the use of the technical summary/indictable distinction in section 80 . It is also preferable to any suggestion that the protection apply in 'serious criminal cases'. ${ }^{91}$ The notion of 'serious' is too vague to provide the basis of such an important right.

Third, it needs to be considered whether the right to a jury trial should extend to courts martial. In accordance with the principle that it is for the Commonwealth to determine whether an offence is to be tried by jury, section 80 has been held not to extend to courts martial. ${ }^{92}$ It is interesting that the right to a jury trial is often excluded from military tribunals, through the operation, for example, of sections 11(f) of the Canadian Charter of Rights and Freedoms and 24(e) of the Bill of Rights Act 1990 (NZ).

Related to this question is the issue of whether a right to a jury trial should also be applicable to civil cases. The United States' Bill of Rights recognises the right to a jury in both criminal and civil cases. Specifically, the Sixth Amendment provides for the right to a fair, ${ }^{93}$ speedy, impartial, public trial by jury in criminal cases. A right to a jury trial is also recognised for civil cases

\footnotetext{
${ }^{89}$ Even though the subject offence, Crimes Act 1914 (Cth) s 30K, carried a penalty of one year imprisonment, the legislation stated that it could be tried summarily.

${ }^{90} R v$ Archdall and Roskruge; ex parte Carrigan and Brown (1928) 41 CLR 128, 136, 139-40. See further $R v$ Federal Court of Bankruptcy; ex parte Lowenstein (1938) 59 CLR 556; Spratt $v$ Hermes (1965) 114 CLR 226 (Barwick CJ); Zarb v Kennedy (1968) 121 CLR 283, 294 (Barwick CJ, McTiernan, Kitto, Taylor and Owen JJ); Li Chia Hsing v Rankin (1979) 141 CLR 182, 202; Kingswell v R (1985) 159 CLR 264; Re Colina; Ex parte Torney (1999) 200 CLR 386, 396, 436-9; Cheng v The Queen (2000) 203 CLR 248.

${ }^{91}$ As suggested by the minority justices who have sought to give s 80 some meaning. See Deane $\mathrm{J}$ in Kingswell $v R(1985) 159$ CLR 264, 310, 318; Murphy J in Li Chia Hsing $v$ Rankin (1979) 141 CLR 182, 202; Kirby J in Cheung $v$ The Queen (2001) 209 CLR 1, 38-9.

${ }^{92}$ In Re Tyler; Ex parte Foley (1994) 181 CLR 18 a majority of the court (Mason CJ, Brennan, Dawson, Toohey and McHugh JJ, Deane and Gaudron JJ dissenting) asserted that the conferral of power on a tribunal to try and punish members of the defence forces breached the separation of judicial powers under Ch III of the Constitution. See also Re Tracey; Ex parte Ryan (1989) 166 CLR 518, 541, 545, 573-4.

${ }^{93}$ This includes a right to legal representation.
} 
by the Seventh Amendment. However, as the right to personal liberty is clearly more important than property rights, there may be a case for limiting the right to a jury trial to criminal matters.

\section{Freedom of Religion}

Section 116 Constitution provides:

The commonwealth shall not make any law for establishing any religion, or for imposing any religious observance, or for prohibiting the free exercise of any religion, and no religious test shall be required as a qualification for any office or public trust under the Commonwealth.

Section 116 prohibits four distinct aspects of governmental involvement in religious matters:

- the establishment of any religion;

- the imposition of any religious observance;

- the prohibition of the free exercise of any religion; and

- the use of religion as a qualification for public office

While section 116 has four heads, nearly all the key cases ${ }^{94}$ have been concerned only with the third clause, the protection of the free exercise of any religion. As detailed below, section 116 is subject to major important limitations that, despite its seeming breadth, have rendered this so-called constitutional guarantee a 'paper tiger'. The paucity of protection afforded by section 116 is remarkable given that the freedom of conscience and religion is one of the most fundamental human rights. It is recognised in leading international instruments, such as Article 18 of the Universal Declaration of Human Rights (1948) and Article 18 of the International Covenant on Civil and Political Rights (1966), and domestic bill of rights instruments, discussed below.

How then should the absence of the protection of religious beliefs be addressed? First, again any reform measures need to extend to the States and Territories, not just the federal government. Whilst section 116 is

\footnotetext{
${ }^{94}$ That is, apart from Attorney-General (Vic); Ex rel Black $v$ Commonwealth (1981) 146 CLR 559 which concerned the prohibition of establishing a religion. A 6:1 majority of the High Court held that, while s 116 prevented the Commonwealth from establishing a particular religion as the official/national religion, s 116 did not prevent the government from providing financial aid to non-government schools, including church schools. This case is known as the 'DOGS case' because a body called Defence of Government Schools initiated the challenge.
} 
incorporated in Chapter V of the Constitution, under the heading 'The States,' 95 the section is expressly confined to Commonwealth laws, to the exclusion of State laws. ${ }^{96}$ Thus, apart from the Tasmanian Parliament, which is constrained by provisions in its own Constitution, ${ }^{97}$ State parliaments are not prevented from carrying out any of the listed acts on the basis of religion. Again, the application of section 116 to the Territories is uncertain. ${ }^{98}$ The protection of freedom of religion should, by contrast, be comprehensive in the Australian jurisdictions.

Second, section 116 should protect Australians from legislation that both directly and incidentally infringes their freedom of religion. Under the current law, section 116 applies only if the express and single purpose of the legislation offends section $116 .{ }^{99}$ This point has been made in the context of both the first ${ }^{100}$ and third ${ }^{101}$ limbs of section 116. A law is no less abhorrent if it achieves its goal of hampering the free exercise of religion whilst also achieving some other objective.

\footnotetext{
${ }^{95} \mathrm{~J}$ La Nauze, The Making of the Australian Constitution (1972) 228-9.

${ }^{96}$ Attorney-General (Vic); Ex rel Black v Commonwealth (1981) 146 CLR 559, 577, 594, 652.

${ }^{97}$ Constitution Act 1934 (Tas) s 34 guarantees the freedom of conscience and religion.

${ }^{98}$ In obiter in Lamshed v Lake (1958) 99 CLR 132, 143 Dixon CJ (with whom Webb, Kitto and Taylor JJ agreed) suggested that s 116 applies to a law enacted under the territories power, and this view was adopted by Toohey, Gaudron and Gummow JJ in Kruger v Commonwealth (1997) 190 CLR 1, 79, 85, 92-3, 96, 114-125, 141, 162, 166-7. A contrary view was adopted by Brennan CJ and Dawson J: (1997) 190 CLR 1, 41-6, 53, 68-70, 73.

${ }^{99}$ Attorney-General (Vic); Ex rel Black v Commonwealth (1981) 146 CLR 559, 579, 615-616, 653; Kruger v Commonwealth (1997) 190 CLR 1, 41, 85-6, 131-132; Minister for Immigration and Ethnic Affairs v Lebanese Moslem Association (1987) 71 ALR 578, 591.

${ }^{100}$ Thus in Attorney-General (Vic); Ex rel Black v Commonwealth a series of Acts which extended to the States financial assistance, subject to conditions including that a proportion of the funds must be given to non-government schools, were held not to have breached s 116 as the legislation did not have the 'purpose and effect of setting up any religion as a state church': (1981) 146 CLR 559, 604 (Gibbs J). See also Mason J in Attorney-General (Vic); Ex rel Black $v$ Commonwealth (1981) 146 CLR 559, 612 and 616; (1981) 146 CLR 559, 610 (Stephen J). Rather the objective of the subject law was to assist secular private schools, as well as church schools, and thus the subject grants could be seen as essentially for educational purposes.

101 In Kruger $v$ Commonwealth a majority of the High Court held that the Aboriginal Ordinance 1918 (Cth) that authorised the removal of Aboriginal children from their families was not invalid as a law must have the purpose of offending s 116 before the law would be invalidated: (1997) 190 CLR 1, 41, 53 and 131-2. While the effect of the Ordinance had been to impair, or even prohibit, the spiritual beliefs and practices of Aboriginal persons, that was not its purpose and thus the Ordinance was not invalidated by s 116: (1997) 190 CLR 1, 85-6 (Toohey J); (1997) 190 CLR 1, 161 (Gummow J). See also Minister for Immigration and Ethnic Affairs v Lebanese Moslem Association (1987) 71 ALR 578, 591.
} 
Third, the High Court's ${ }^{102}$ distinction in Krygger $v$ Williams ${ }^{103}$ between laws (i) prohibiting the doing of acts required by religion (which are prohibited) and (ii) requiring the doing of acts prohibited by religion (which are not prohibited) must be rejected. Under this view only positive acts required by a religion are protected and, it will be seen, then only if they are not contrary to the general community's interest. A religion-based pacifism $^{104}$ is consequently not protected. A prohibition against blood transfusions and a religious requirement to respect the Sabbath by, inter alia, not working on that day, provide further examples of religious requirements that are not protected. Taken to its extremes, the above distinction gives rise to absurd consequences. For example, a religion requiring human sacrifice would seemingly be protected by section 116 as human sacrifice is an act required by the religion. ${ }^{105}$ For reasons such as this, the United States' courts, with respect to their equivalent provision, have long rejected this distinction.

Thus reform measures need to embrace language that makes it clear that the protection extends, not just to positive acts of worship, but also to the abstaining from certain acts. Article 18(1) of the International Covenant on Civil and Political Rights, for example, provides for the 'freedom of thought, conscience and religion' and states that this includes the freedom of a person to 'manifest his religion or belief in worship, observance, practice and teaching'. Article 18(2) specifically provides that '[n]o one shall be subject to coercion which would impair his freedom to have or to adopt a religion or belief of his choice'. Thus the protection of 'observance' and the prohibition on coercing a person to act in a way contrary to religious beliefs could address these concerns. Such general protections might also be complemented by specific clauses. For example, while section 15 of the Bill of Rights Act 1990 (NZ) similarly protects the right to 'manifest' a person's religion in 'worship, observance, practice or teaching', section 11 includes a right to refuse to undergo any medical treatment. The latter is of course relevant to the refusal to undergo a blood transfusion or other medical procedure on religious grounds.

\footnotetext{
${ }^{102}$ Constituted by only two members of the High Court, Griffith CJ and Barton J.

${ }^{103}$ (1912) 15 CLR 366.

104 That underpinned the factual basis of both Krygger $v$ Williams (1912) 15 CLR 366 and Adelaide Company of Jehovah's Witnesses v Commonwealth (1943) 67 CLR 116. In regard to the Buddhist faith and pacifism see 'Buddhism and war': http://www.bbc.co.uk/ religion/religions/buddhism/buddhistethics/war.shtml.

${ }^{105}$ Note, however, that the qualification to $\mathrm{s} 116$ that provides that the right to freedom of religion can be constrained when the public interest so requires will prevent this example actually being protected under s 116 .
} 
The fourth, and most difficult, issue that needs to be addressed in such reforms is the degree of absoluteness of the protection. The protection afforded by section 116 is far from absolute and can be overridden by, inter alia, ${ }^{106}$ the public interest. ${ }^{107}$ Thus, in Adelaide Company of Jehovah's Witnesses $v$ Commonwealth, the High Court unanimously held that activities which a religion requires but which the community 'in general' regards as "unsocial ${ }^{108}$ or 'subversive ... [or] dangerous to the common weal" ${ }^{109}$ might validly be prohibited. ${ }^{110}$ For this reason, section 116 has proven ineffective in preventing the mistreatment of non-Anglo-Irish religious groups, such as the Muslim community, ${ }^{111}$ where the general interests of the Australian community have overridden the Muslim community's religious and community interests. Relevantly, all but one banned organisation under the Commonwealth anti-terrorism laws ${ }^{112}$ are Islamic. In light of the related offence of supporting such banned associations, these laws obviously impact on the Muslim community.

The United States Bill of Rights provides an example of an absolute freedom of religion. The First Amendment provides that 'congress shall make no law respecting any establishment of religion, or prohibiting the free exercise thereof ...'. Logic dictates, however, that there must be some limits to the free exercise of religion. Human rights are rarely absolute. Using the example mentioned earlier in this article, a religious conviction involving human

\footnotetext{
${ }^{106}$ It can also be avoided through s 96 grants: Attorney-General (Vic); Ex rel Black $v$ Commonwealth (1981) 146 CLR 559, 593. Section 96 allows the Commonwealth to make grants to the States. A practice of attaching conditions to such monies is now well established. Thus monies could be provided to a State on the condition that it is used for roads or, as in this case, for funding private schools.

${ }^{107}$ Thus in Adelaide Company of Jehovah's Witnesses $v$ Commonwealth the National Security (Subversive Association) Regulations that required the outright dissolution of this religious group were held to be valid, the court finding that s 116 did not entitle the Jehovah's Witnesses to advocate doctrines prejudicial to the war: (1943) 67 CLR 116, 155 (Starke J); 159 (Williams J); 149 (Rich J).

${ }^{108}$ Ibid 155 (Starke J).

${ }^{109}$ Ibid 149-50 (Rich J).

${ }^{110}$ See also ibid 159 (Williams J).

${ }^{111}$ Australian Muslim communities, for example, have suffered considerable discrimination generally, but particularly since the introduction of the above anti-terrorism laws. See the Australian Muslim Civil Rights Advocacy Network fact sheets: 'New anti-terror laws and the Muslim community - a plain English explanation' http://www.communitylaw.org.au/cb_pages/ anti_terrorism_laws.php; HREOC, above n 25 .

${ }^{112}$ Crimes Act 1914 (Cth) Part II includes offences in regard to unlawful associations.
} 
sacrifice cannot be protected. Similarly, a religious conviction that involves the abuse or degradation of animals or humans ${ }^{113}$ cannot be protected.

In recognition of the need for some legitimate limitations, even the United States Supreme Court has adopted a 'balancing' approach to its religious guarantees that will at times allow the public interest to override a specific group's religious beliefs. ${ }^{114}$ Nevertheless the Australian High Court's suggestion that general community interests can prevail over minority rights is disturbing. Consider the rationale for introducing section 116 into the Constitution. Surely it was designed to protect those who otherwise lack the political or numerical influence to protect their rights. Yet it is the beliefs of this very group that Starke and Rich $\mathrm{JJ}^{115}$ in Adelaide Company of Jehovah's Witnesses $v$ Commonwealth suggest should be overridden by the majority. Whilst there will be occasions where inconsistent rights will have to be balanced, ${ }^{116}$ the statement of Starke and Rich JJ accords too little importance to the protection of individual rights and does not sit comfortably with the imperative opening words of section 116, 'The Commonwealth shall not ...'

Thus a narrower application of the balancing test needs to be identified. What limits could acceptably be placed on the free exercise of religion? Latham CJ makes a valid point in Adelaide Company of Jehovah's Witnesses $v$ Commonwealth $^{117}$ that for a person to be able to exercise religion freely, the State in which that freedom can be exercised must continue to exist. ${ }^{118}$ Hence it is 'consistent with the maintenance of religious liberty for the State to restrain actions and courses of conduct which are inconsistent with the maintenance of civil government or prejudicial to the continued existence of the community'. ${ }^{119}$ Thus, the continued existence of the State must necessarily prevail over the free exercise of religion. This point is particularly pertinent in the so-called 'Age of Terror'. However, extreme care is needed to ensure that underlying fears about terrorist attacks do not lead to discrimination against innocent persons.

\footnotetext{
${ }^{113}$ Care needs to be taken in regard to claims of degradation. For example, protocols that could appear degradatory to women might be based on historical/cultural protectionary norms.

${ }^{114}$ See further the discussion of the United States' approach in Adelaide Company of Jehovah's Witnesses v Commonwealth (1943) 67 CLR 116.

${ }^{115}$ (1943) 67 CLR 116, 155 (Starke J); 149-50 (Rich J).

${ }^{116}$ A narrow scope for the overriding of religious freedoms was suggested by Mason ACJ and Brennan J in Church of New Faith v Commissioner of Pay-roll Tax (Vic) (1983) 154 CLR 120 They commented that the 'freedom to act in accordance with one's religious beliefs is not as inviolate as the freedom to believe ...', adding that such actions cannot be accorded immunity where they offend non-discriminatory laws.

117 (1943) 67 CLR 116, 131-2 (with whom McTiernan J agreed).

${ }^{118}$ Ibid

${ }^{119}$ Ibid.
} 
The Victorian Charter of Rights and Responsibilities 2006 recognises the right to enjoy cultural practices, to exercise a religion and to speak a language: section 19. However, the rights stated in the Charter are subject to a general limitation: they may be subject to reasonable limits under the law having regard to all relevant factors: section 7(2). Similarly, section 2 of the Canadian Charter of Rights and Freedoms recognises as a 'Fundamental freedom ... freedom of conscience and religion' but also provides in section 1 that the freedom is subject 'to such reasonable limits prescribed by law as can be demonstrably justified in a free and democratic society'. ${ }^{120}$ Section 36(1) of the Constitution of the Republic of South Africa 1996 contains a similar provision, but also states in section 31(2) that the right to, inter alia, practise religion 'may not be exercised in a manner inconsistent with any provision of the Bill of Rights'. Article 18(3) of the International Covenant on Civil and Political Rights is a little more specific, only allowing legislative limitation of the freedom of religion to 'protect public safety, order, health, or moral or fundamental rights and freedoms of others'. Thus these human rights instruments provide useful guidance as to how to balance the private right to exercise religion with the private rights of other citizens and the maintenance of the broader society.

\section{Freedom from Interstate Discrimination}

Section 117 of the Constitution provides:

A subject of the Queen, resident in any State, shall not be subject in any other State to any disability or discrimination which would not be equally applicable to him if he were a subject of the Queen resident in such other State.

Broadly speaking, the impact of section 117 is that one State may not impose on the residents of another State some disability that is not imposed equally on residents of the first State. Section 117 continues to be a potentially important provision in contemporary Australia as it endeavours to achieve the equal treatment of the residents of different States. As Mason CJ stated in Street $v$ Queensland Bar Association, ${ }^{121}$ "[ $\left.\mathrm{t}\right] \mathrm{his}$ section is one of the comparatively few provisions in the Constitution which was designed to enhance national unity and a real sense of national identity by eliminating disability or discrimination on account of residence in another State'. In a

\footnotetext{
${ }^{120}$ Note that section 5 of the Bill of Rights Act 1990 (NZ) contains the same 'reasonable limits prescribed by law as can be demonstrably justified in a free and democratic society' test. ${ }^{121}$ (1989) 168 CLR 461, 485; see also 583-4 (McHugh J).
} 
modern federation such as Australia the equal treatment of citizens continues to be an important human right.

Yet, despite the grand sentiments underlying section 117, it has proven to be largely ineffective in protecting even the right to equality, let alone the freedom of movement. Section 117's failure stems from two sources. First, the section has racist foundations, despite being inspired by Article IV of the United States Constitution of 1789. ${ }^{122}$ Article IV provides: 'The citizens of each State shall be entitled to all privileges and immunities of citizens in the several States. ${ }^{123}$ During the drafting of section 117 the use of the United States' concepts of 'due process' and 'equal protection', which have provided great sources of judge-made constitutional law in the United States, were defeated because it was believed that they would invalidate laws based explicitly on racial discrimination. ${ }^{124}$ The concern was that laws which today would universally be regarded as abhorrent due to their discrimination against Aboriginal, Islander and Asians persons, but which were at the time regarded by government entities as essential, might be invalidated by the clause. ${ }^{125}$ For example, the State of Western Australia was adamant about the need to exclude Asian persons from its goldfields and would not support a clause that prevented it passing racially based laws. ${ }^{126}$ How different the history of civil liberties in Australia might have been had the United States' concepts made it into the final text of the Commonwealth Constitution.

Second, the courts' approach in many section 117 cases has clearly been too technical. The leading cases on section 117 suggest once again that the courts have rendered a constitutional guarantee a matter of semantics that can be easily circumvented by clever legislatures. It will be seen that section 117 is subject to six possible limitations that should be addressed through reform.

\footnotetext{
${ }^{122}$ See Street v Queensland Bar Association (1989) 168 CLR 461, 485 (Mason CJ).

${ }^{123}$ See La Nauze, above $\mathrm{n} 95,68$. Note that the Canadian Charter of Rights and Freedoms (1982) contains two clauses that are relevant to the application of s 117. Section 6 specifies certain mobility rights. Section 6(2)(b) extends to every permanent resident of Canada the right 'to pursue the gaining of a livelihood in any province'. This protection is subject to 'any laws or practices of general application in force in a province other than those that discriminate among persons primarily on the basis of province of present or previous residence': s 6(3)(a). The right is also subject to 'any laws providing for reasonable residency requirements as a qualification for the receipt of publicly provided social services': s 6(3)(b). Under s 15(1) there is also a general right to equality under the law, without discrimination.

${ }^{124}$ See H Charlesworth, 'Individual Rights and the Australian High Court' (1986) Law in Context 53, 113.

${ }^{125}$ See ibid.

${ }^{126}$ See also the discussion of Lee Fay $v$ Vincent (1908) 7 CLR 389, below.
} 
First, in contrast to the constitutional provisions discussed above, there is no case authority suggesting that section 117 applies to the Commonwealth. Section 117 is clearly aimed primarily at the States. ${ }^{127}$ Like section 116 , section 117 is contained in Chapter V of the Constitution, entitled 'The States'. In the case of section 117, however, its constitutional location actually reflects its application. While the Commonwealth is prevented from discriminating between the States in some respects by sections other than section 117, notably sections 51(ii), 92 and 99 of the Constitution, the prohibition in section 117 does not include the Commonwealth. This deficiency needs to be addressed.

Second, section 117 applies only if residence is the sole basis of the discrimination. ${ }^{128}$ Thus, if the discrimination is on the basis of residence and domicile, ${ }^{129}$ even though these often coincide, section 117 will not apply because it is legally possible that a person could be resident in Western Australia, but domiciled elsewhere. ${ }^{130}$ Such reasoning is clearly absurdly technical, particularly given that the two prongs of the double-barrelled criterion of discrimination, namely, residence and domicile, are so closely related. A preferable approach can be found in the Canadian Charter of Rights and Freedoms. The mobility rights protected under section 6(2) are subject to 'any laws or practices of general application in force in a province other than those that discriminate among persons primarily on the basis of province of present or previous residence': section 6(3)(a). This clause would require the court to determine whether residency was the primary basis for discrimination.

Third, section 117 applies only if the person being discriminated against is resident in a State other than the legislating State. It does not apply if that person is a resident in the legislating State. Thus in Lee Fay $v$ Vincent ${ }^{131}$ the High Court held that section 117 did not apply as the 'section only applies to a person who, being resident in one State, is seeking to assert rights in another. In the present case the person in respect of whom the rights are asserted is a resident in Western Australia, not in another State, and the rights are asserted in Western Australia.' ${ }^{132}$ Section 117 should simply be concerned with discrimination on the basis of residence per se. It should not

\footnotetext{
${ }^{127}$ See Street v Queensland Bar Association (1989) 168 CLR 461, 485 (Mason CJ).

${ }^{128}$ Davies and Jones $v$ Western Australia (1904) 2 CLR 29, 39 (Griffith CJ), 47 and 49 (Barton J), 53 (O’Connor J).

${ }^{129}$ As in Davies and Jones $v$ Western Australia (1904) 2 CLR 29.

${ }^{130}$ Ibid 39 (Griffith CJ), 47 and 49 (Barton J), 53 (O'Connor J).

131 (1908) 7 CLR 389.

${ }^{132}$ Ibid (Griffith CJ, Barton and O'Connor JJ).
} 
matter whether a State or Territory is effectively discriminating in favour of or against its own residents.

Fourth, in Lee Fay $v$ Vincent ${ }^{133}$ the High Court also held that section 117 only prohibits discrimination on the basis of current residency. ${ }^{134}$ Section 117 is impotent to prevent discrimination by one State on the basis of previous residence in another State. Again the Canadian Charter provides a useful reform model that could perhaps be augmented to ensure that the dominance of substance over form is assured. The mobility rights recognised under section 6(2) of the Charter are protected from 'any laws or practices ... that discriminate among persons primarily on the basis of province of present or previous residence': section 6(3)(a).

Fifth, since only a 'subject of the Queen' can invoke section 117, its protection might not extend to persons who are not Australian citizens. ${ }^{135}$ Brennan J also suggested in Street $v$ Queensland Bar Association that it might protect only natural persons and thus might not extend to artificial persons, for example companies. ${ }^{136}$

Sixth, section 117 is not absolute. The courts have recently asserted that section 117 does not apply to laws that discriminate on the basis of residence in a way that is 'appropriate and adapted (sometimes described as "proportional") to the attainment of a proper objective'. ${ }^{137}$ The difficult question once again is to determine the absoluteness of the protection(s). Should it be absolute, as under the United States' Constitution, or subject to some limitation? The right to freedom of movement ${ }^{138}$ and right to reside throughout the relevant state ${ }^{139}$ are recognised in a number of bills of rights. However, commonly these rights are stated to be subject 'to such reasonable limits prescribed by law as can be demonstrably justified in a free and democratic society'. ${ }^{140}$ What limits could be justified? Can discrimination on

\footnotetext{
${ }^{133}$ Ibid.

${ }^{134}$ Ibid.

${ }^{135}$ Street v Queensland Bar Association (1989) 168 CLR 461, 525 (Deane J), 541 (Dawson J), 554 (Toohey J).

${ }^{136}$ Ibid 505 (Brennan J); Sweedman v Transport Accident Commission (2006) 226 CLR 362, 408 (Gleeson CJ, Gummow, Kirby and Hayne JJ).

137 Sweedman v Transport Accident Commission (2006) 226 CLR 362, 409-10 (Gleeson CJ, Gummow, Kirby and Hayne JJ).

${ }^{138}$ In, for example, Charter of Rights and Responsibilities 2006 (Vic) s 12; Bill of Rights Act 1990 (NZ) s 18; Constitution of the Republic of South Africa 1996 s 21(1).

${ }^{139}$ In, for example, Canadian Charter of Rights and Freedoms s 6(2); Bill of Rights Act 1990 (NZ) s 18; Constitution of the Republic of South Africa 1996 s 21(3).

${ }^{140}$ Canadian Charter of Rights and Freedoms s 6(2). Bill of Rights Act 1990 (NZ) s 5; Constitution of the Republic of South Africa 1996 s 36(1) contains a similar provision.
} 
the basis of residency ever be justified? Can a State legitimately restrict to its own residents the right of franchise for electing its legislature ${ }^{141}$ Is a resident of one State entitled to welfare benefits that another State provides exclusively to its residents? ${ }^{142}$ Section 6(3)(b) of the Canadian Charter of Rights and Freedoms recognises the legitimacy of laws that provide for 'reasonable residency requirements as a qualification for the receipt of publicly provided social services'. Can a State encourage local industry by adding a figure of, for example, $10 \%$ to the cost of out-of-State tenders for government contracts? In many cases, a State will be able to pursue a policy of protecting the legitimate interests of the State without using residence as the operative factor. For example, there would obviously be no constitutional objection to Queensland conditioning its bail laws, not on residence within the State, but on the likelihood of the accused fleeing the jurisdiction. ${ }^{143}$ Similarly, competence to practise law might be tested in ways other than insisting on a period of residence. ${ }^{144}$ In other cases, however, such as franchise in State elections and perhaps the provision of benefits or services paid for through State taxes, the criterion of residence may be defended as a reasonable requirement.

Perhaps, as Mason CJ suggests, ${ }^{145}$ each of these difficult cases needs to be tested by asking whether the discrimination would 'detract from the concept of Australian nationhood or national unity which is the object of the section to ensure'. Alternatively, McHugh J asserts that the 'question is not whether a particular subject-matter serves the object of section 117 ; it is whether, by necessary implication, the matter is so exclusively the concern of the State and its people that an interstate resident is not entitled to equality of treatment in respect of it'. ${ }^{146}$ Perhaps it is necessary to include in any bill of rights instrument some specific guidance as to the balance between State autonomy and discrimination on the basis of residence.

\section{IMPLiEd CONSTITUtional RightS}

\footnotetext{
${ }^{141}$ See further Street v Queensland Bar Association (1989) 168 CLR 461, 491, 513, 528, 548, 560,570 and 584 .

${ }^{142}$ Baldwin v Montana Fish and Game Commission 436 US 371 (1978), 383. See Street v Queensland Bar Association (1989) 168 CLR 461, 491-2 (Mason CJ).

${ }^{143}$ See Re Loubie [1986] 1 Qd R 272.

${ }^{144}$ See also Street v Queensland Bar Association (1989) 168 CLR 461, 493 (Mason CJ).

${ }^{145}$ Ibid 492 (Mason CJ).

${ }^{146}$ Ibid 584.
} 
Before concluding this discussion of the paucity of existing constitutional protections, it would be remiss not to consider whether the framework of the Constitution may provide implied rights that serve as a further source of constitutional protection. ${ }^{147}$

The process of recognising implied constitutional protections began with Murphy J in the late 1970s and early 1980s. Murphy J believed that certain implied rights were 'part of the fabric of the Constitution', ${ }^{148}$ namely:
- the implied freedom of movement, speech and other communication; ${ }^{149}$
- $\quad$ the implied freedom from slavery; ${ }^{150}$ and
- the implied freedom from arbitrary discrimination on the basis of sex. ${ }^{151}$

It was not until the 1990s, however, that the notion of implied constitutional protections was adopted by a majority of High Court justices. In more recent times certain members of the Australian High Court have suggested that a number of implied guarantees can be extrapolated from the nature and scheme of the Constitution. Some of these implied guarantees include:

- $\quad$ the right to procedural fairness; $;^{152}$

\footnotetext{
${ }^{147}$ See further McHugh, above $\mathrm{n} 2$.

148 Miller v TCN Channel Nine Pty Ltd (1986) 161 CLR 556, 581. Note that Dawson J subsequently criticised Murphy J's suggestion that such protections are impliedly protected by the Constitution: Australian Capital Television v Commonwealth (1992) 177 CLR 106, 186. See McHugh, ibid.

${ }^{149}$ Ansett Transport Industries (Operations) Pty Ltd v Commonwealth (1977) 139 CLR 54, 88; Buck v Bavone (1976) 135 CLR 110, 137; McGraw-Hinds (Aust) Pty Ltd v Smith (1979) 144 CLR 633, 670; Uebergang v Australian Wheat Board (1980) 145 CLR 266, 312; Miller v TCN Channel Nine Pty Ltd (1986) 161 CLR 556, 581-2.

${ }^{150} R v$ Director-General of Social Welfare (Vic); Ex parte Henry (1975) 133 CLR 369, 388.

${ }^{151}$ Ansett Transport Industries (Operations) Pty Ltd v Wardley (1980) 142 CLR 237, 267.

${ }^{152}$ Implied from Chap II Constitution: Chu Kheng Lim v Minister for Immigration (1992) 176 CLR 1, 27 and 29 (Brennan, Deane, and Dawson JJ); Re Tracey; Ex parte Ryan (1989) 166 CLR 518, 580 (Deane J); Re Tyler; Ex parte Foley (1993) 181 CLR 18, 34 (Deane J); Polyukhovich v Commonwealth (1991) 172 CLR 501, 607 and 614-5 (Deane J), 684-5 and 689 (Toohey J), 703-4 (Gaudron J); Leeth v Commonwealth (1992) 174 CLR 455, 470 (Mason CJ, Dawson and McHugh JJ), 486-7 (Deane and Toohey JJ), 502-3 (Gaudron J). Note that the minority justices in Leeth recognised a broader right to equality: 485 and 487-8 (Deane and Toohey JJ), 502-3 (Gaudron J). Section 4(1) Commonwealth Prisoners Act 1967 (Cth) directed a court when determining a non-parole period to be guided by the law of the State or Territory in which the Commonwealth offender was convicted. These laws varied considerably from State to State. It was argued that s 4(1) was invalid as it authorised the unequal treatment of offenders depending on the State/Territory in which they were convicted. Deane, Toohey and
} 
- the right to vote; ${ }^{153}$

- the right to proper administration of the judicial power; ${ }^{154}$ and

- the implied freedom of political communication. ${ }^{155}$

As with the express constitutional guarantees, however, and exemplified in the context of the implied freedom of political communication, the Australian High Court has been particularly mindful of the need to interpret implied protections narrowly. Members of the High Court have asserted that the implied freedom of political communication:

- $\quad$ is to be narrowly construed and is confined to what is necessary to give effect to the terms and structure of the Constitution, rather than what is necessary to give effect to representative and responsible government; ${ }^{156}$

Gaudron JJ agreed, asserting that the legislation breached a right to equality that was implicit in Ch III Constitution: 487 (Deane and Toohey JJ); 502-3 (Gaudron J). Note that Mason CJ, Brennan, Dawson and McHugh JJ held that the law did not breach any constitutional requirement: 467-468. See further C Parker, 'Protection of Judicial Process as an Implied Constitutional Principle' (1994) 16 Adelaide Law Review 341; L Zines, 'A Judicially Created Bill of Rights?' (1994) 16 Sydney Law Review 166; G Winterton, 'Separation of Judicial Power as an Implied Bill of Rights' in G Lindell (ed), Future Directions in Australian Constitutional Law (1994), 185; F Wheeler, 'The Doctrine of Separation of Powers and Constitutionally Entrenched Due Process in Australia' (1997) 23 Monash University Law Review 248; F Wheeler, 'Due Process, Judicial Power and Chapter III in the New High Court' (2004) 32 Federal Law Review 205.

${ }_{153}$ Attorney-General (Cth); Ex rel McKinlay v Commonwealth (1975) 135 CLR 1, 36 (McTiernan and Jacobs JJ); Roach v Electoral Commissioner (2007) 233 CLR 162, 173-4 (Gleeson CJ), 198-9 (Gummow, Kirby and Crennan JJ), 206 (Hayne J).

${ }^{154}$ ALPA Ltd v Legal Services Commissioner (2005) 224 CLR 322s, 432 (Kirby J).

${ }^{155}$ Implicit in the system of representative government prescribed by the Constitution is the freedom of discussion of political and governmental affairs: Australian Capital Television v Commonwealth (1992) 177 CLR 106, 138-9 (Mason CJ), 149 (Brennan J), 168 (Deane and Toohey JJ), 210 (Gaudron J) and 227-8 (McHugh J); Nationwide News Pty Ltd v Wills (1992) 177 CLR 1, 47-9 (Brennan J), 71-3 (Deane and Toohey JJ) and 94 (Gaudron J). See also Mulholland v Australian Electoral Commission (2004) 220 CLR 181, 219-220 (McHugh J). In Australian Capital Television v Commonwealth (1992) 177 CLR 106 legislation that prohibited certain types of political advertising during election periods was held to be invalid for breaching this principle. In Nationwide News Pty Ltd v Wills (1992) 177 CLR 1 legislation that made it an offence to use words calculated to bring a member of the Industrial Relations Commission into disrepute was held to have breached this principle.

${ }^{156}$ Lange v Australian Broadcasting Corporation (1999) 189 CLR 520, 566-7. See also McGinty v Western Australia (1996) 186 CLR 140, 269 (McHugh J). In McGinty a majority of the High Court held that there was no guarantee of 'one vote, one value' implied in the Constitution. 
- $\quad$ is not absolute. ... [and] will not invalidate a law enacted to satisfy some other legitimate end if the law satisfies two conditions; ${ }^{157}$ will not apply if the law has an object that is compatible with representative and responsible government. If the law is 'reasonably appropriate and adapted to achieving that end' it will be valid despite the implied freedom; ${ }^{158}$

- is a constraint on legislative power, rather than conferring an individual personal right; ${ }^{159}$

- 'is not an obligation to publicise ... [I]t is not a right to require others to provide a means of communication': ${ }^{160}$

- will only apply where there is some relevant 'right or privilege ... under the general law' that is being infringed; ${ }^{161}$

- does not protect statutory rights as rights created by statute can be reduced by statute. ${ }^{162}$

A useful example of this unwillingness to construe these implied protections broadly, or to extend them, can be found in the High Court case of Kruger $v$ Commonwealth, ${ }^{163}$ discussed above in the context of section 116. The Ordinance considered in that case was said to be unconstitutional on a number of bases including that it:

- $\quad$ breached section 116 of the Constitution Act 1901 (UK);

- $\quad$ breached an implied constitutional freedom against being removed and detained without the benefit of the due process of law;

\footnotetext{
${ }^{157}$ Lange v Australian Broadcasting Corporation (1999) 189 CLR 520, 567-8.

${ }^{158}$ Ibid. Note that, as the diversion of thought in the subsequent case Coleman v Power (2004) 220 CLR 1 evidences, there is considerable uncertainty as to the legal effect of this case. Thus, while in this case all justices applied Lange, the High Court was divided 4:3 as to whether the subject legislation was inconsistent with the implied freedom of political communication. See also Mulholland v Australian Electoral Commission (2004) 220 CLR 181, 305 (Heydon J).

${ }^{159}$ Lange $v$ Australian Broadcasting Corporation (1999) 189 CLR 520, 567. See also Levy v Victoria (1997) 189 CLR 579, 605 (Dawson J), 620 (McHugh J), 628 (Kirby J). More generally, in Kruger $v$ Commonwealth the court asserted that a breach of any alleged constitutional rights did not give rise to any entitlement to damages: (1997) 190 CLR 1, 46-7 (Brennan CJ), 93 (Toohey J), 125-6 (Gaudron J), 147 (Gummow J).

${ }^{160}$ McClure v Australian Electoral Commission (1999) 163 ALR 734, 740-1 (Hayne J); Mulholland v Australian Electoral Commission (2004) 220 CLR 181, 303 (Heydon J), contra 267-8 (Kirby J).

${ }^{161}$ Levy v Victoria (1997) 189 CLR 579, 662; Mulholland v Australian Electoral Commission (2004) 220 CLR 181, 223 (McHugh J), 298 (Callinan J), 303 (Heydon J), contra 276 (Kirby J).

${ }^{162}$ Mulholland v Australian Electoral Commission (2004) 220 CLR 181, 223 (McHugh J), 298 (Callinan J), 305 (Heydon J).

163 (1997) 190 CLR 1. See also ALPA Ltd v Legal Services Commissioner (2005) 224 CLR 322 as a further example of an unwillingness to expand the implied freedoms.
} 
- breached an implied constitutional right of equality under the law; and breached an implied constitutional freedom of movement and association.

Brennan CJ, ${ }^{164}$ Dawson $\mathrm{J}^{165}$ (with whom McHugh J agreed ${ }^{166}$ ) and Gummow $\mathrm{J}^{167}$ rejected the existence of the alleged implied constitutional freedoms. In regard to the implied requirement of 'legal equality', these justices asserted that some provisions of the Constitution (sections 51(ii), 51(iii), 51(xix), 51 (xxvi), 88, 92, 99 and 117) contemplate 'legislative inequality'. ${ }^{168}$ In regard to the implied right to freedom of movement and association, Brennan CJ asserted that no 'such right has hitherto been held to be implied in the Constitution and no textual or structural foundation for the implication has been demonstrated in this case' ${ }^{169}$ The judges denied that such a right was a 'corollary of that freedom of communication about government and political matters which is implied in the Constitution ..., 170

Moreover, as noted above, Brennan $\mathrm{CJ}^{171}$ and Dawson $\mathrm{J}^{172}$ also held that section 122 (the 'Territories' power) extended to the Commonwealth an absolute legislative power with respect to the Territories that was not subject to any express or implied constitutional prohibition. Thus, if the alleged implied right to legal equality existed, the Ordinance, which 'treated Aboriginal children differently from other children' would nevertheless be validly enacted under section $122 .{ }^{173}$ Toohey, Gummow and Gaudron JJ disagreed on this point, asserting that section 122 was not necessarily immune from express (s 116) or implied constitutional protections. ${ }^{174}$ However, Toohey and Gummow JJ held that if section 122 was subject to the

\footnotetext{
164 (1997) 190 CLR 1, 46. Brennan CJ found it unnecessary to consider many of the grounds put forward by the plaintiffs as he believed the Ordinance (i) was not intended to inflict mental harm and (ii) was not intended to prohibit the free exercise of religion. This meant that the crux for him was whether s 122 was limited by these constitutional restrictions: 41 .

${ }^{165} \mathrm{Ibid} 63$ and 68-70. Dawson J asserted that the right to due process was procedural in nature and thus did not provide a substantive right or freedom: 69 .

${ }^{166}$ Ibid 142-4.

${ }^{167}$ Ibid 153-9.

${ }^{168}$ Ibid 45 (Brennan CJ), see also 64 (Dawson J), 155 (Gummow J).

${ }^{169}$ Ibid 45.

${ }^{170}$ Ibid 45 (Brennan CJ), see also 155 (Gummow J).

${ }^{171}$ Ibid 41. Once there was a sufficient connection between the law and the Territories, the Territories power was said to be without limitation: 41 .

${ }^{172}$ Ibid 56, 68-70 and 73.

${ }^{173}$ Ibid 42 (Brennan CJ).

${ }^{174}$ Ibid 79, 85, 92-3 and 96 (Toohey J), 162 and 166-7 (Gummow J), 114-125 and 141 (Gaudron J).
} 
alleged constitutional rights, the Ordinance had not breached them. ${ }^{175}$ Only Gaudron $\mathrm{J}$ in her dissent stated a belief that the Ordinance breached the implied constitutional freedom of movement and association. ${ }^{176}$ The Ordinance conferred powers which directly constrained the freedom of movement and association by, for example, requiring Aboriginal persons to remain on reserves and by removing Aboriginal children from their families and detaining them in Aboriginal institutions. ${ }^{177}$

All indications suggest that this narrowing of any implied constitutional protections will continue. Recently retired Justice Callinan has criticised Lange $v$ Australian Broadcasting Corporation, ${ }^{178}$ not because of its narrowing of the implied constitutional protection, but for its very recognition of the implied protection. ${ }^{179}$ Callinan $\mathrm{J}$ rejected the existence of the implied constitutional freedom of communication, adding that 'the authors of the Constitution were well aware of the First Amendment to the Constitution of the United States and most deliberately must have chosen not to incorporate such a provision in our Constitution' ${ }^{180}$ Not long before his appointment to the High Court, Heydon J extra-curially criticised Lange $v$ Australian Broadcasting Corporation ${ }^{181}$ and 'judicial activism' generally as the 'illegitimate' use of the judicial function to further 'some political, moral or social program'. ${ }^{182}$

Implied constitutional rights will certainly not constitute a set of rights obviating the need for a federal bill of rights. Moreover, the courts' attitude to the legal relevance of a breach of both express and implied constitutional provisions (ie the inability to seek damages) indicates that, even when breached, implied constitutional rights might not provide an adequate remedy in a given case.

\footnotetext{
${ }^{175}$ Ibid 93 and 97 (Toohey J).

${ }^{176}$ Ibid 127.

${ }^{177}$ Ibid 128.

178 (1999) 189 CLR 520.
}

179 Australian Broadcasting Corporation v Lenah Game Meats Pty Ltd (2001) 208 CLR 119, 330-331; Roberts \& Case v Bass (2002) 212 CLR 1, 101-2. See, however, Kirby J's response: Australian Broadcasting Corporation v Lenah Game Meats Pty Ltd (2001) 208 CLR 119, 285286; Roberts \& Case v Bass (2002) 212 CLR 1, 55.

${ }^{180}$ Australian Broadcasting Corporation v Lenah Game Meats Pty Ltd (2001) 208 CLR 119, 330-331. More generally, see Callinan J's comments as to the relevance of international human rights law in Western Australia $v$ Ward (2002) 213 CLR 1, 389.

181 (1999) 189 CLR 520.

182 'Judicial Activism and the Death of the Rule of Law' (2003) Jan-Feb Quadrant 9. 


\section{The Lack of Specifically Aboriginal Rights}

Unlike the Canadian Charter of Rights and Freedoms, ${ }^{183}$ the Commonwealth Constitution contains no section protecting Aboriginal rights. In fact the Commonwealth Constitution is far from a protective document when it comes to the Aboriginal peoples of Australia. In addition to section 51(xxxi), discussed above, which obviously has a potential impact on the extinguishment of Aboriginal title, ${ }^{184}$ three provisions of the Constitution were/are relevant to the Aboriginal peoples of Australia; namely sections 25, 127 and 51(xxvi).

Sections 25 and 127 are interrelated. Section 25 qualifies section 24. The latter provides that the House of Representatives is to be 'chosen in the several States ... in proportion to the respective numbers of their people'. Regarding the calculation of the number of people in a State or in the Commonwealth, section 25 provides that if a State law disqualifies a race from voting in elections, 'persons of that race resident in that State shall not be counted.' Thus section 25 accommodated the State disenfranchisement of Aboriginal persons under Acts such as the Constitutional Acts Amendment Act 1899 (WA) and Elections Act 1885 (Qld) and excluded such persons from being taken into account in determining State representation in the House of Representatives under section 24. Aboriginal persons were not counted in the population of a State when determining the number of seats of Parliament that could be held by representatives of that State. Such State disenfranchisement meant that Aboriginal persons were also ineligible to vote in the referendum that approved the adoption of the Commonwealth Constitution. ${ }^{185}$ In this regard it is also pertinent to note the Commonwealth disenfranchisement of Aboriginal persons under section 4 of the Commonwealth Franchise Act 1902 (Cth). ${ }^{186}$ Commonwealth

\footnotetext{
${ }^{183}$ In particular the right to use a native language under s 23 and the general protection of aboriginal rights under $\mathrm{s} 35$.

${ }^{184}$ While it has not been conclusively determined, it was suggested in Mabo v Queensland (No 2) (1992) 175 CLR 1, 111 and Newcrest Mining (WA) Ltd v Commonwealth (1997) 190 CLR 513, 613 that s 51(xxxi) applied when aboriginal title was extinguished. Note that the Native Title Amendment Act 1998 (Cth), which allows for, inter alia, the extinguishment of native title, provides compensation on 'just terms'.

${ }^{185}$ Hanks, above n 34, 91.

${ }^{186}$ Note that this section was stated to be subject to s 41 of the Constitution, which preserved the right to vote in the case of persons with State franchise at federation. Note that it did not apply to persons who obtained State franchise post-federation: $R v$ Pearson; Ex parte Sipka (1983) 152 CLR 254. Section 41 would have served to protect the voting rights of the small
} 
disenfranchisement of Aboriginal persons was not completely removed until 1962 through the Commonwealth Electoral Act 1962 (Cth).

Section 25 was in turn bolstered by section 127 which provided that '[i]n reckoning the numbers of the people of the Commonwealth, or of a State or other part of the Commonwealth, Aboriginal natives shall not be counted'. Thus, under the Constitution, the traditional peoples of Australia were not counted as Australians in the census.

Sections 25 and 127 were both based on the 14th Amendment to the United States Constitution that excludes 'Indians not taxed' from the federal census. By way of explanation, the sovereignty of the Aboriginal peoples of the United States is recognised through a notion called 'domestic dependent sovereignty'. The Indian tribes of the United States have long been recognised as domestic dependent Nations, exercising inherent sovereign rights over Indian country ${ }^{187}$ concurrently with the United States government's claim to sovereignty. ${ }^{188}$ The sovereignty of Indian Nations became entrenched in the United States case law as a result of a series of cases that have come to be known as the "Marshall trilogy'. ${ }^{189}$ According to

number of aboriginal persons entitled to State franchise at federation: ibid 93. See further the discussion at ibid 93-4.

${ }^{187}$ In essence, Indian country constitutes (i) reservations, (ii) dependent Indian communities and (iii) allotments of lands the aboriginal title to which has not been extinguished. See Bates $v$ Clark 95 US 204 (1877); Clairmont v US 225 US 551 (1912); Donnelly v US 228 US 243 (1913); US v Chavez 290 US 357 (1933); In re McCord 151 F Supp 132 (1957); US v Martine 442 F 2d 1022 (1971); DeCoteau v District County Court 420 US 425 (1975); Indian Country, USA Inc v Oklahoma 829 F 2d 967 (1987); California v Cabazon Band of Mission Indians 480 US 202 (1987); Citizen Band Potawatomi Indian Tribe of Oklahoma v Oklahoma Tax Com 888 F 2d 1303 (1989); Cardinal v US 954 F 2d 359 (1992); US v Sands 968 F 2d 1058 (1992); Narragansett Indian Tribe of Rhode Island v Narragansett Electric Co 878 F Supp 349 (1995); Pittsburg \& Midway Coal Mining Co v Watchman 52 F 3d 1531 (1995); Oklahoma Tax Com v Chickasaw Nation; Mustang Production Co v Harrison 94 F 3d 1382; Ute Indian Tribe v Utah 935 F Supp 1473 (1996); Oneida Indian Nation of New York v City of Sherrill, New York 337 F 3d 139 (2d Cir, 2003). See also Federal Criminal Code 18 USCA s 1151. See further American Jurisprudence $2 d$ (2005) vol 41, [170]-[171]; D Getches and C Wilkinson, Cases and Materials on Federal Indian Law ( $5^{\text {th }}$ ed, 2005) chap 7; F Cohen, Handbook of Federal Indian Law (University of Mexico Press, 2005); www.answers.com/topic/indian-territory; www.indianlandtenure.org; www.indiancountry.com; www.historycooperative.org/journals/ $\mathrm{cp} /$ vol-02/no-01/cheyfitz.hrtm.

${ }^{188}$ See also Lane v Pueblo of Santa Rosa 249 US 110 (1919); American Vantage Companies Inc $v$ Table Mountain Rancheria 292 F 3d 1091 ( $9^{\text {th }}$ Cir, 2002); US v Long 324 F 3d 475 ( $7^{\text {th }}$ Cir, 2003) Kizis v Morse Diesel Int Inc 206 Conn 46 (2002); Ackerman v Edwards 121 Cal App 4th 946 (2004); US v Lara 541 US 193 (2004).

189 Johnson v McIntosh 21 US 543, 574 (1923); Cherokee Nation v Georgia 30 US 1, 16, 17, 20 and 53 (1831); Worcester v Georgia 31 US 515, 544-5 and 559 (1932). 
the 'Marshall trilogy', these Indian Nations had to be left in the undisturbed possession of their lands, the right to which was only diminished to a limited extent by the new sovereign's right of pre-emption. ${ }^{190}$ It was recognised that Indian tribes, as separate Nations, were entitled to govern themselves and enforce their own customary laws. This sovereignty allowed Indian Nations to regulate affairs within the scope of their territory, exercising authority over matters such as community membership, domestic relations between members, fish and game resources and taxation, ${ }^{191}$ and enjoying sovereign immunity from suit. ${ }^{192}$ Hence, the reference to 'Indians not taxed' relates to those Indian persons living in a self-governing Indian Nation that is not subject to federal tax. Thus the $14^{\text {th }}$ Amendment was transplanted into the Australian Commonwealth Constitution even though the sovereignty of the Aboriginal peoples was not recognised in Australia.

In 1967 section 127 was removed from the Constitution as a consequence of one of the few successful referenda on the amendment of the Constitution. Thus it was not until 1967 that the Aboriginal peoples of Australia were recognised as being Australian persons for the purposes of censuses. Section 25, however, was not repealed as a result of the 1967 referendum and still remains in this form in the Constitution.

\footnotetext{
${ }^{190}$ That is, the sole right as against other European nations to purchase the Indians' lands if they wish to sell. Marshall CJ described the right of pre-emption in Johnson v McIntosh 21 US 543, 573 (1923): 'This principle was, that discovery gave title to the government by whose subjects, or by whose authority, it was made, against all other European governments, which title might be consummated by possession. The exclusion of all other Europeans necessarily gave to the nation making the discovery the sole right of acquiring the soil from the natives, and establishing settlements upon it.'

${ }^{191}$ See Washington $v$ Confederated Bands and Tribes of Yakima Indian Nation 439 US 436 (1979); Montana v US 450 US 544 (1981); Merrion v Jicarilla Apache Tribe 455 US 130 (1982); Conoco Inc v Shoshone and Arapahoe Tribes 569 F Supp 801 (1983); Southland Royalty Co v Navajo Tribe of Indians 715 F 2d 486 (1983); Kerr-McGee Corp v Navajo Tribe of Indians 731 F 2d 597 (1984); Queets Band of Indians v Washington 765 F 2d 1399 (1985); US v Anderson 736 F 2d 1358 (1984); Burlington Northern Railroad v Fort Peck Tribal Executive Board 701 F Supp 1493 (1988); Burlington Northern Railway Co v Blackfeet Tribe of Blackfeet Indian Reservation 924 F 2d 899 (1991); Atkinson Trading v Shirley 531 US 1009 (2000); Burlington Northern Santa Fe Railway Co v Assiniboine and Sioux Tribes of Fort Peck Reservation 323 F 3d 767 ( $9^{\text {th }}$ Cir, 2003). See further Getches, above n 188, chap 8; Cohen, above $\mathrm{n} 188$.

${ }^{192}$ See In re Absher Children 141 Ohio App 3d 118 (2001); Roe v Doe 649 NW 2d 566 (ND, 2002); NLRB v Pueblo of San Juan 276 F 3d 1186 (10 ${ }^{\text {th }}$ Cir 2002); State v Moses 145 Wash 2d 370 (2002); Atkinson Trading v Shirley 531 US 1009 (2000); Kizis v Morse Diesel Int Inc 206 Conn 46 (2002); State v Manypenny 682 NW 2d 143 (2004); Sanchez v Santa Ana Golf Club Inc 104 P 3d 548 (2004).
} 
Section 51(xxvi), known as the 'races' power, originally extended to the Commonwealth legislative authority over ' $[t]$ he people of any race, other than the Aboriginal race in any state, for whom it is deemed necessary to make special laws...' Thus originally the federal Parliament had no specific power to pass laws in regard to the Aboriginal peoples of Australia. The Commonwealth legislative authority to pass laws dealing with Aboriginal persons, such as the Aboriginal Ordinance 1918 (Cth) considered above in Kruger $v$ Commonwealth, ${ }^{193}$ was based on the other non-race-specific sections of the Constitution. In this case the primary source of legislative power was section 122, the 'Territories' power. Section 51(xxvi) reflected the fact that, historically, Aboriginal affairs were regarded as a State matter. Despite federation occurring in 1901 and despite the federal Parliament having authority over the Territories from this date, ${ }^{194}$ it was not until 1911 that the Commonwealth became responsible for the Northern Territory ${ }^{195}$ and passed laws regulating the rights and lives of Aboriginal persons, for example the Aboriginals Ordinance 1911 (Cth).

In 1967, in the referendum discussed above, section 51(xxvi) was amended by deleting the words 'other than the Aboriginal race in any state'. Thus section 51(xxvi) can now be used by the Commonwealth to enact laws regarding Aboriginal peoples. Under the Constitution, unless stated otherwise, the legislative powers of the federal Parliament, including those outlined in section 51(xxvi), are concurrent with the States' powers. This contrasts with the position in the United States and Canada where most powers with respect to Aboriginal persons are held exclusively by the federal government. ${ }^{196}$

There have been very few cases on section 51(xxvi) and these cases have generally ${ }^{197}$ involved legislation supported by other heads of legislative

\footnotetext{
${ }^{193}$ (1997) 190 CLR 1.

${ }^{194}$ See Constitution Act 1901 (UK) s 122. Note in regard to the Australian Capital Territory that under the Aborigines Welfare Act 1954 (Cth) aboriginal persons residing in this Territory were subject to any relevant New South Wales legislation.

${ }^{195}$ The Northern Territory was originally annexed to South Australia and this historical fact explains why State legislation applied to the aboriginal peoples of the Northern Territory postfederation. See, for example, the Northern Territory Aboriginal Act 1910 (SA).

${ }^{196}$ See United States' Constitution 1789 Article 1; British North America Act 1869 s 91(24). See Hanks, above n 34, 107.

${ }^{197}$ Western Australia v Commonwealth (1995) 183 CLR 373, 461 concerned s 51(xxvi), but also the operation of s 109 in regard to inconsistent Western Australian laws. Controversially, in this case the High Court held that the Native Title Act 1993 (Cth) was not racially discriminatory and thus was not contrary to the Racial Discrimination Act 1975 (Cth). See
} 
power. Therefore, section 51(xxvi) has not been the sole or primary focus of these cases. ${ }^{198}$ The key unresolved issue in regard to section 51(xxvi) is whether it can be used to discriminate against Aboriginal persons, rather than discriminating in their favour. Murphy $\mathrm{J}$ in Koowarta v Bjelke-Petersen ${ }^{199}$ and the Tasmanian Dam case $e^{200}$ and Brennan ${ }^{201}$ and Deane ${ }^{202} \mathrm{JJ}$ in the latter case suggested that section 51(xxvi) could only be used to pass laws that benefit Aboriginal persons. It was reasoned that the 1967 amendment indicated that racially discriminatory policies were to come to an end and the 'primary object of the power is beneficial. ${ }^{203}$ Similarly, Kirby $\mathrm{J}$ in Kartinyeri $v$ Commonwealth ${ }^{204}$ asserted that the history of section 51(xxvi), including the 1967 amendment, indicates that the word 'for' was intended to be interpreted as 'for the benefit'. Justice Gaudron ${ }^{205}$ in the same case asserted that, to be valid under section 51(xxvi), a law must be 'appropriate and adapted to [a race's] different circumstances. ${ }^{, 206}$ She also asserted that it is difficult to conceive of circumstances in which a law presently operating to the disadvantage of a racial minority would be valid.' This was particularly so in regard to Aboriginal Australians. ${ }^{207}$

However, there are contrary dicta in Koowarta $v$ Bjelke-Petersen ${ }^{208}$ and Western Australia v Commonwealth. ${ }^{209}$ Such a contrary view was adopted by

further J Clarke, The Native Title Amendment Bill 1997: A Different Order of Uncertainty? Centre for Aboriginal Economic Policy Discussion Paper 144/97 (1997, ANU).

${ }^{198}$ Thus in Koowarta v Bjelke-Petersen (1982) 153 CLR 168 and the Tasmanian Dam case (1983) 158 CLR 1 the focus was also on the external affairs power and Parliament's ability to enact laws domestically incorporating international conventions. In Koowarta v BjelkePetersen (1982) 153 CLR 168 five members of the court (Gibbs CJ, Aickin, Stephen, Wilson and Brennan JJ; Mason and Murphy JJ not deciding) held that s 51(xxvi) did not support the enactment of the Racial Discrimination Act 1975 (Cth). In the Tasmanian Dam case (1983) 158 CLR 1 a majority of the court (Mason, Murphy, Brennan and Deane JJ) held that s 51(xxvi) supported provisions of the World Heritage Properties Conservation Act 1983 (Cth) protecting Aboriginal cultural heritage.

199 (1982) 153 CLR 168, 242.

${ }^{200}$ (1983) 158 CLR $1,80$.

${ }^{201}$ Ibid 242.

${ }^{202}$ Ibid 273.

${ }^{203}$ Ibid 242.

204 (1998) 195 CLR 337, 413 and 416. Consequently, he held the Hindmarsh Island Bridge Act 1997 (Cth) to be invalid under s 51(xxvi).

${ }^{205}$ (1998) 195 CLR 337, 363-8. See also Gaudron J in Kruger v Commonwealth (1997) 190

CLR 1.

${ }^{206}$ (1998) 195 CLR 337, 367.

${ }^{207}$ Ibid 367-8.

${ }^{208}$ (1982) 153 CLR 168, 186 (Gibbs J).

209 (1995) 183 CLR 373, 461. 
Gummow and Hayne JJ in Kartinyeri v Commonwealth ${ }^{210}$ and also appears to have been supported by Brennan $\mathrm{CJ}$ and McHugh $\mathrm{J}$ in the same case. ${ }^{211}$ Under this view, section 51(xxvi) could provide a specific source of power to enact legislation that displaces the Racial Discrimination Act 1975 (Cth), ${ }^{212}$ in the manner described above. How disturbing the possibility is that section 51(xxvi) might be used to pass laws that impact negatively on a race is shown by the Solicitor-General's response to a question from Kirby $\mathrm{J}$ in Kartinyeri $v$ Commonwealth. ${ }^{213}$ When asked if section 51(xxvi) could be used to validly enact Nuremberg-style race laws or South African apartheid laws, the Solicitor-General unhesitatingly replied in the affirmative, adding that the section gives a power to pass what may be described as inherently a discriminatory law'. ${ }^{214}$

The constitutional position of the Aboriginal peoples of Australia is abhorrent, both because of the express provisions of the Constitution and the absence in it of recognition and protection of Aboriginal rights. Any reform involving the adoption of a bill of rights instrument needs to address the historical discrimination against the Aboriginal peoples of Australia under the Constitution in a number of ways:

First, while the repugnant State legislation disenfranchising Aboriginal persons that provided section 25 with its foundations was ultimately repealed, in some cases as late as $1965,{ }^{215}$ it is nevertheless disturbing that section 25 remains in the Constitution and indirectly condones racist State laws. ${ }^{216}$ As

\footnotetext{
${ }^{210}$ (1998) 195 CLR 337, 382. See also Dawson J in Kruger v Commonwealth (1997) 190 CLR 1.

211 (1998) 195 CLR 337, 355-357. They asserted that if the Commonwealth had legislative authority under s 51(xxvi) to pass the Heritage Protection Act 1984 (Cth), it had power to partially repeal that Act. While they did not specifically address whether s 51(xxvi) only allowed beneficial laws, as this amendment impacted negatively on the Ngarrindjeri people, they must have believed that s 51(xxvi) was not so limited.

${ }^{212}$ See McHugh, above $\mathrm{n} 2$.

213 (1998) 195 CLR 337.

${ }^{214}$ Quoted in McHugh, above n 2.

${ }^{215} 1962$ in the case of Western Australia (Electoral Act Amendment Act 1962 (WA)) and 1965 in the case of Queensland Election Acts Amendment Act 1965 (Qld)). See also Hanks, above $\mathrm{n}$ 34,87 and 92 .

${ }^{216}$ The validity of any such laws today is another question. Clearly they would breach the Racial Discrimination Act 1975 (Cth). Thus Hanks (ibid 92) notes that the ability of the States to impose such racial restrictions has been doubted in McGinty $v$ Western Australia (1996) 186 CLR 140.
} 
suggested by the Council for Aboriginal Reconciliation, ${ }^{217}$ it should be removed from the Constitution.

Second, it must be made clear that section 51(xxvi) cannot be used to discriminate against the Aboriginal peoples of Australia. As noted earlier, the Racial Discrimination Act 1975 (Cth) has failed to protect Aboriginal people from racially discriminatory legislation and policies. Equally, as Kruger $v$ Commonwealth $^{218}$ indicates, constitutional implications do not provide a source of protection. Thus an express provision preventing discrimination on the basis of race is needed to adequately protect Aboriginal persons. To this end, the preamble to the Charter of Rights and Responsibilities 2006 (Vic) recognises that the Charter is founded on notions of 'equality and freedom' and states that 'human rights belong to all people without discrimination, and the diversity of the people of Victoria enhances our community'. Section 8(3) of the Victorian Charter also provides that 'Every person is equal before the law and is entitled to the equal protection of the law without discrimination and has the right to equal and effective protection against discrimination'. Sections 9(3) and (4) of the Constitution of the Republic of South Africa 1996 and section 15(1) of the Canadian Charter of Rights and Freedoms also address this issue by specifically prohibiting discrimination on the basis of, inter alia, race.

Third, the cultural rights of Aboriginal peoples should be expressly recognised and protected. Section 19(1) of the Charter of Rights and Responsibilities 2006 (Vic) provides that a person with a particular cultural background "must not be denied the right, in community with other persons of that background, to enjoy his or her culture ...219 Importantly in this context, section 19(2)(a) specifically recognises and protects the cultural rights of Aboriginal persons and section 19(2)(c) protects their right to 'maintain their kinship ties'.

Fourth, the right of Aboriginal peoples to speak their traditional language should be expressly recognised and protected. Again, section 19(1) of the Charter of Rights and Responsibilities 2006 (Vic) provides that a person with a particular linguistic background 'must not be denied the right, in community with other persons of that background ... to use his or her

\footnotetext{
217 Reconciliation: Australia's Challenge (Final Report, 2000) www.austlii.edu.au/au/oter/ IndigLRes/car/2000/16.

${ }^{218}$ (1997) 190 CLR 1.

${ }^{219}$ See also Constitution of the Republic of South Africa 1996 ss 30 and 31; Bill of Rights Act 1990 (NZ) s 20.
} 
language ${ }^{, 220}$ and section 19(2)(b) specifically recognises and protects the right of Aboriginal persons to maintain and use their language. More controversial is whether a right to education in a traditional language should be protected. Section 23 of the Canadian Charter of Rights and Freedoms recognises the rights in regard to primary and secondary school instruction in English or French, but does not address Aboriginal languages. Section 29(2) of the Constitution of the Republic of South Africa 1996 provides that all persons have the right to receive education in the language of their choice in a public educational institution, where that is 'reasonably practicable'.

Fifth, a bill of rights instrument might also recognise Aboriginal customary law. This issue has been extensively addressed in the ALRC Report, Recognition of Aboriginal Customary Laws. ${ }^{221}$ This of course gives rise to difficult issues, particularly in the context of criminal law and punishment. At least the recognition of customary family law should be considered. It is relevant in this context that section 15(3) of the Constitution of the Republic of South Africa 1996 condones legislation that recognises traditional marriages and 'systems of personal and family law under any tradition'. However, the recognition of such traditions must be consistent with the rest of the provisions of the South African Constitution.

Sixth, Aboriginal rights, including land rights, should be recognised and protected. As noted above, the Racial Discrimination Act 1975 (Cth) has not been effective in protecting Aboriginal land rights. In this regard section 19(1) of the Charter of Rights and Responsibilities 2006 (Vic) provides some guidance in its recognition of the right of Aboriginal persons to 'maintain their distinctive spiritual, material and economic relationship with the land and waters and other resources with which they have a connection under traditional laws and customs'. More generally, section 35(1) of the Canadian Charter of Rights and Freedoms recognises and affirms the 'Aboriginal and treaty rights of the Aboriginal peoples of Canada'.

Finally, it would be appropriate to recognise the Aboriginal peoples of Australia as the traditional owners of the country. To this end the preamble of the Charter of Rights and Responsibilities 2006 (Vic) recognises the special importance of human rights for the 'Aboriginal people of Victoria, as descendants of Australia's first people, with their diverse spiritual, social, cultural and economic relationship with their traditional lands and waters'.

\footnotetext{
${ }^{220}$ See also Constitution of the Republic of South Africa 1996 ss 30 and 31; Bill of Rights Act 1990 (NZ) s 20.

${ }^{221}$ Report No 31 (AGPS, Canberra, 1986).
} 


\section{CONCLUSION}

From the above analysis it will be apparent that the Commonwealth Constitution contains hollow avowals of human rights. It contains very few human rights provisions and, where the constitutional drafters did purport to protect a right, judicial interpretation has narrowed the right exceedingly. The four key so-called protections considered in this article particularly exemplify this proposition. As the above critical analysis shows, all four provisions have been emasculated by judicial interpretations, supported to some extent by poor constitutional drafting. It must be accepted that the narrow view of these sections is largely supported by the majority justices of, in particular, the High Court of Australia. These constitutional provisions, despite often being founded upon the United States' Constitution, do not provide an effective source of human rights protections in Australia. Equally, the courts will not use the Constitution as a source of implied constitutional rights. The paucity of rights in the Constitution, coupled with the inadequacy of any other sources of human rights in Australia, suggests that a new source of rights is needed $-\mathrm{a}$ federal bill of rights.

It must be recognised, however, that the analysis in this article is part of a broader debate as to whether Australia should adopt a federal bill of rights. That the Constitution provides a weak source of human rights does not conclusively establish the need for a federal bill of rights. This article comprises just one component in the discussion of whether the people of Australia need a federal bill of rights. Thus, it is pertinent to conclude by briefly placing the article in the context of the arguments for and against such a bill of rights.

Until now the case against an Australian bill of rights has largely been based on the notion that a bill of rights will confer on the unelected judiciary legislative and executive powers, contrary to democratic principles. ${ }^{22}$ However, under a legislative bill of rights the courts are typically only given the power to declare that legislation is contrary to the stated protections. ${ }^{223}$ Only the legislature can actually invalidate a law. As discussed below, the

\footnotetext{
${ }^{222}$ Anderson, above n 3; Editorial, above n 3; Clement, above n 3; Evans above n 3; K Nguyen, 'Independent Charter' The Age 28 July 2006.

${ }^{223} \mathrm{~J}$ Cassidy, 'The Victorian Charter of Human Rights and Responsibilities - A Model for a Federal Bill of Rights?' Faculty of Law, University of Ottawa, Ottawa, Canada, 12 January 2007. See further the discussion below of the Charter of Human Rights and Responsibilities 2006 (Vic).
} 
Charter of Human Rights and Responsibilities 2006 (Vic) accords with such a model.

Opponents of the Charter of Human Rights and Responsibilities 2006 (Vic) nevertheless continue to assert that it confers too much power on unelected judges. ${ }^{224}$ Perhaps blind to the reality of the operation of the Charter, they continue to assert that the Victorian courts can effectively strike down a law that breaches human rights and that this capacity effects a revolutionary 'shift in the balance of power between the elected Parliament and the unelected judges'. ${ }^{225}$ This is a considerable overstatement of the courts' powers under the Charter. Under section 36 of the Charter the Supreme Court of Victoria or Victorian Court of Appeal can declare that a statute is incompatible with a human right. The declaration does not invalidate the statute, nor give rise to any civil cause of action in an aggrieved person: sections 36(5) and 39(3). Section 36 confers a power of judicial review, but nothing more. As stated above, the ability to amend or repeal the law continues to reside solely with Parliament.

It has also been contended that a bill of rights will lead to a litigation culture. ${ }^{226}$ However, the barriers to litigation, such as costs and locus standi, will help prevent vexatious litigation. For this reason, in the United Kingdom there was almost no increase in litigation following the enactment of the Human Rights Act 1998 (UK). The Human Rights Act 1998 (UK) was raised in less than $.05 \%$ of criminal cases heard in the Crown Court following its enactment. Indeed, most of the cases referred to in the recent British Review of the Implementation of the Human Rights Act (2006) did not go to court. ${ }^{227}$ Moreover, a legislative bill of rights typically does not extend private rights of action. Thus, while, as noted above, under section 36 of the Charter of Human Rights and Responsibilities 2006 (Vic) the Supreme Court of Victoria or Court of Appeal can declare that a statute is incompatible with a human right, the declaration does not give rise to any civil cause of action in an aggrieved person: sections 36(5) and 39(3). ${ }^{228}$

Interrelated with the above is the suggestion that a bill of rights will have the effect of making judges 'more activist' because, it is stated, Parliament is no

\footnotetext{
${ }^{224}$ Anderson, above n 3; Clement, above n 3; Faris, above $\mathrm{n} 7$.

${ }^{225}$ Anderson, ibid; Clement, ibid; Faris, ibid.

${ }^{226}$ See McHugh, above $\mathrm{n} 2$.

${ }^{227}$ Department of Constitutional Affairs, Review of the Implementation of the Human Rights Act (2006) (www.justice.gov.uk/docs/full_review.pdf). See von Doussa, above n 12.

${ }^{228}$ See Nguyen, above n 223; Cassidy, above n 224.
} 
longer supreme. ${ }^{229}$ It is said that the power to declare laws incompatible with human rights will reflect individual judges' personal and political views and this will politicise the bench. ${ }^{230}$ Implicit in this is the suggestion that the declaratory powers under the Charter are somehow more 'powerful' than the courts' existing powers to invalidate laws where these laws, for example, breach constitutional law. Respectfully, how such a declaratory power is going to politicise the bench is far from clear. Moreover, the British experience suggests that such a claim is without empirical foundation. ${ }^{231}$ Ultimately, if a court declares an Act to breach a fundamental human right and the government responds to this through an amendment, how is that undemocratic? Is that not a positive feature of the bill of rights? ${ }^{232}$

It has also been suggested that it is naive to believe that a bill of rights will eliminate human rights abuses through legislative and executive actions, as bills of rights have existed in the past in oppressive regimes. ${ }^{233}$ Contemporary events have shown, however, that the United States' Bill of Rights of 1791 has provided effective protection against government abuse and, as stated above, the Human Rights Act 1998 (UK) was the impetus for the United Kingdom Parliament amending, inter alia, its anti-terrorist laws and securing the release of English Guantanamo Bay detainees. ${ }^{234}$ Equally, in the absence of a federal bill of rights in Australia, as noted above, human rights abuses in Australia have been committed by the federal government.

In regard to the framework that such a federal bill of rights might take, should it be constitutional or legislative in nature? A constitutional model provides a more enduring source of protection of human rights as the Constitution cannot be readily amended. ${ }^{235}$ On the other hand, constitutional models are criticised as being frozen in time and thus unable to adapt to a changing society. ${ }^{236}$ They are seen as too inflexible because of the state's inability to readily amend their terms. ${ }^{237}$ In this regard it is interesting to consider how current the protections under the United States'Bill of Rights are, despite their having been adopted in 1791. For the reasons delineated,

\footnotetext{
${ }^{229}$ See McHugh, above n 2.

230 See ibid.

${ }^{231}$ See Department of Constitutional Affairs, above n 228; von Doussa, above n 12.

${ }^{232}$ See K Kissane, 'Exerting a moral force' The Age 8 January 2008.

${ }^{233}$ Anderson, above $\mathrm{n} 3$.

${ }^{234}$ Department of Constitutional Affairs, above n 228. See von Doussa, above n 12.

${ }^{235}$ See McHugh, above $\mathrm{n} 2$.

${ }^{236}$ See ibid.

${ }^{237}$ See the discussion of this issue in Cassin, above $\mathrm{n} 2$; Nguyen, above $\mathrm{n}$ 223. In response, it is interesting to consider the currency of the protections under the United States' Bill of Rights.
} 
legislative models are often seen as having a number of preferable features; in particular their ability to be amended more readily than a constitutional provision. ${ }^{238}$ As noted above, constitutional models are also perceived as extending to the judiciary too much power, contrary to democratic principles. It has been suggested, however, that the impartial courts are better placed to protect the rights of the marginalised members of society as parliaments lack the time, expertise and political will to protect such members of society. ${ }^{239}$

A further issue relating to the model of the relevant bill of rights is the question already raised above, namely whether the courts should have power to invalidate legislation that breaches the rights in question. As noted above, under a legislative bill of rights the courts are typically given the power to declare that legislation is contrary to the stated protections, but only the legislature can actually invalidate the laws. ${ }^{240}$ This model has the benefit of avoiding the above-discussed perception of a judicial usurpation of Parliament's legislative power. It has been effective in the United Kingdom where Parliament has responded to judicial declarations by modifying the offending laws. ${ }^{241}$ Only time will tell whether judicial 'shaming' of the Victorian Parliament will suffice and whether it would be preferable for the courts to have power to invalidate contrary legislation, as under the United States' Bill of Rights.

Thus this article must be seen in the broader context of the many entwined issues that need to be considered in the debate regarding the pros and cons of a federal bill of rights.

\footnotetext{
${ }^{238}$ As to whether the Charter of Human Rights and Responsibilities Act 2006 (Vic) provides a model for a legislative federal Bill of Rights see Cassidy, above n 224. In regard to the Human Rights Act 2005 (ACT) see H Charlesworth and G McKinnon, Australia's First Bill of Rights: The Australian Capital Territory's Human Rights Act (2006). In regard to the Human Rights Act 1998 (UK) see the discussion in Attorney-General Lord Goldsmith, above n 32; HREOC, above n 12; von Doussa, above n 12; J Debeljak, 'The Human Rights Act 1998 (UK): 'The preservation of parliamentary supremacy in the context of rights protection' [2003] Australian Journal of Human Rights 10.

${ }^{239}$ Evans, above n 3; Mason, above n 3.

${ }^{240}$ Cassidy, above $\mathrm{n} 223$.

${ }^{241}$ Attorney-General Lord Goldsmith, above n 32. See further HREOC, above n 12; von Doussa, above n 12. See also the discussion of the role of the Human Rights Act 19998 (UK) in protecting human rights in Debeljak, above n 238.
} 